\title{
Health Considerations Regarding Horizontal Transfer of Microbial Transgenes Present in Genetically Modified Crops
}

\author{
Gijs A. Kleter, Ad A. C. M. Peijnenburg, and Henk J. M. Aarts \\ RIKILT, Institute of Food Safety, Wageningen University and Research Center, PO Box 230, 6700AE Wageningen, The Netherlands
}

Received 18 October 2004; revised 30 May 2005; accepted 1 June 2005

\begin{abstract}
The potential effects of horizontal gene transfer on human health are an important item in the safety assessment of genetically modified organisms. Horizontal gene transfer from genetically modified crops to gut microflora most likely occurs with transgenes of microbial origin. The characteristics of microbial transgenes other than antibiotic-resistance genes in market-approved genetically modified crops are reviewed. These characteristics include the microbial source, natural function, function in genetically modified crops, natural prevalence, geographical distribution, similarity to other microbial genes, known horizontal transfer activity, selective conditions and environments for horizontally transferred genes, and potential contribution to pathogenicity and virulence in humans and animals. The assessment of this set of data for each of the microbial genes reviewed does not give rise to health concerns. We recommend including the above-mentioned items into the premarket safety assessment of genetically modified crops carrying transgenes other than those reviewed in the present study.
\end{abstract}

\section{INTRODUCTION}

The cultivation of genetically modified (GM) crops has rapidly increased since their large-scale commercial introduction in 1996. The acreage of GM crops in 2004 amounted to 81 millions of hectares worldwide, while the number of nations that adopt GM crop cultivation was also increasing [1]. Before GM crops and other genetically modified organisms (GMOs) are allowed to enter the market, the law in many nations requires that these organisms and/or derived products be assessed for their safety. To this end, the applicant, which is in most cases a company that has developed and produced a GMO, provides a dossier to the national authorities, which, among others, contains safety data. Whereas national laws and regulatory procedures may differ among each other, the regulatory safety assessment itself follows an internationally harmonised approach. International organisations like the United Nations' Food and Agriculture Organisation (FAO) and World Health Organisation (WHO) as well as

Correspondence and reprint requests to Gijs A. Kleter, RIKILT, Institute of Food Safety, Wageningen University and Research Center, PO Box 230, 6700AE Wageningen, The Netherlands, E-mail: gijs.kleter@wur.nl

This is an open access article distributed under the Creative Commons Attribution License which permits unrestricted use, distribution, and reproduction in any medium, provided the original work is properly cited. the Organisation for Economic Cooperation and Development (OECD) and International Life Sciences Institute (ILSI) have initiated this harmonisation. It has recently culminated into the issuance of FAO/WHO Codex Alimentarius guidelines for the safety assessment of foods derived from GM plants and microorganisms [2]. Central in the harmonised approach is the comparative safety assessment, which entails the comparison of a GMO with a conventional counterpart that has a history of safe use [3]. This comparison may include, for example, phenotypic characteristics (eg, field behaviour) and composition (eg, macronutrients, micronutrients, antinutrients) of a GMO and its comparator. Based upon the differences found during the comparison between the GMO and its comparator, it can be decided which further safety tests are needed. Issues that are commonly addressed during the safety assessment include the molecular characterisation (eg, introduced genes), the potential for horizontal gene transfer, potential allergenicity, potential toxicity, nutritional characteristics, environmental effects, and unintended effects of the genetic modification (reviewed in $[4])$.

\section{Horizontal gene transfer}

Various mechanisms exist for horizontal gene transfer between microorganisms, such as phage transduction, conjugation, and transformation by free DNA (eg, [5]). The possible scenario for gene transfer between GM crops and microorganisms is, however, limited to transformation with free DNA. 
A number of studies and reviews have focused on the transfer of genes from GM plants to soil- and plantrelated microorganisms (eg, $[6,7,8,9,10])$. The results of some of these studies indicated that transgenes from GM crops are most likely transferred if they contain sufficient similarity with the corresponding genes in the recipient because homologous recombination is the most probable mechanism of transfer (eg, [11]). It has, however, recently been observed that under conditions of simulated lightning, which might cause electroporation of recipient cells, DNA could be transferred to isolated soil microbes [12].

Other factors that are important for transformation with DNA are the natural or induced competence of the recipient microorganisms, such as the natural competence of Campylobacter species. Some microorganisms, such as Salmonella typhimurium, have mismatch repair systems that form a barrier for recombination between even highly similar sequences (eg, reviewed for Salmonella by [13]). Some bacteria can develop natural/chemical competence under certain environmental conditions [6].

In addition, the transgenes in plants may have been linked to promoters with optimal activity in the cells of plants. Sequences promoting expression in eukaryotes and prokaryotes are generally known to be different. Nevertheless, Jacob et al [14] observed that eukaryotic promoters from, for example, the cauliflower mosaic virus, potato, and tobacco, triggered expression of inserted reporter genes in five eubacterial species. In addition, Lewin et al [15] observed that random sequences from yeast may exhibit promoter activity in bacteria.

Jonas et al [16] estimated the potential dietary intake of transgenic DNA present in food. The estimated intake of transgenic DNA from maize, soya, and potatoes amounted to approximately $0.38 \mu \mathrm{g}$ per day, assuming that only GM crops are consumed. This is about $0.00006 \%$ of the total DNA intake of $0.6 \mathrm{~g}$ per day.

Still this is a "worst-case" scenario as DNA is prone to degradation in food matrices or during food processing (reviewed in [16]). On the other hand, also the protection of DNA against the activity of DNase I in, for instance, fermented sausages has been described [17].

In addition, the integrity of the DNA is countered by the activity of DNA degrading enzymes released by the pancreas and intestinal epithelial cells during its passage through the gastrointestinal tract. Nevertheless, it has been shown that DNA can persist in the gastrointestinal tract $[16,18,19]$ and consequently be available for uptake by intestinal competent bacteria. For example, the survival of cp4 epsps transgenes in the small intestines of human volunteers who consumed a GM soy product has recently been demonstrated in a study by Netherwood et al [20], so there is a chance for exposure of intestinal microorganisms to free transgenic DNA. However, the preferential site for transformation of competent bacteria is probably in the colon. This is because the colon contains the largest population of bacteria within the gastrointestinal tract. Whilst the amount of DNA reaching the colon may only be a fraction of what is consumed, DNA is less rapidly degraded there. For example, ex vivo and in vivo rat models simulating human gut conditions showed that DNA is rapidly degraded in the upper part of the gastrointestinal tract, but to a lesser degree in the lower part [19].

Besides the integrity of DNA, the transformability, that is, the likelihood that this DNA will transform bacteria in food or in the gut, should be taken into account. In foods, transformation of Escherichia coli by plasmid transfer was proven to occur in all 12 food products investigated [21]. In addition, transfer of DNA to Streptococcus gordonii was also proven in homogenates of blood sausages by marker rescue experiments [22]. Kharazmi et al [23] observed the transfer of nptII kanamycin resistance marker gene from transgenic potatoes to Bacillus subtilis with defective nptII by homologous recombination under in vitro conditions. Based upon the observed frequencies of transfer, these authors calculated the probability of the transfer of the intact nptII gene from consumed transgenic potatoes to microbes. Because marker rescue by homologous recombination is the most probable mechanism for gene transfer, these calculations can be considered a "worst-case" scenario in view of other possible mechanisms of horizontal transfer of transgenes from GM crops.

\section{Potential health effects}

Currently, the focus of the assessment of potential transfer from GMOs is on antibiotic-resistance marker genes, as, for example, in the previously mentioned FAO/ WHO Codex Alimentarius guidelines. In a more general sense, antibiotic resistance among microbial human pathogens is currently a top priority issue in health care and research. The horizontal gene transfer of antibiotic-resistance genes between microorganisms has been important for the development of antibioticresistant pathogens.

In modern biotechnology, some antibiotic-resistance marker genes are used for the successful molecular cloning in bacteria and plants because they enable growth on antibiotic-containing media after the genetic modification process. These marker genes are therefore useful in the development phase, but have no function in the final product. An example of an antibiotic-resistance gene that is present in many commercial GM crops is the kanamycin-resistance gene $n p t I I$ encoding the neomycin phosphotransferase II enzyme. The use of this gene has been considered to be safe based upon the widespread occurrence of kanamycin resistance in microorganisms in the environment, the low clinical relevance of kanamycin, and the low likelihood of transfer to microorganisms after consumption of GM products containing nptII (eg, reviewed by [5]).

For a more elaborate discussion on mechanisms of gene transfer, antibiotic-resistance genes, and horizontal gene transfer from GM crops, as well as a classification of antibiotic-resistance markers based upon their risk characteristics, we refer to a recent review by the working 
group on horizontal gene transfer of the EU-sponsored thematic network ENTRANSFOOD [5].

Besides the horizontal transfer of antibiotic-resistance genes, the transfer of "pathogenicity islands" has played an important role in the evolution of pathogenic strains of microorganisms, such as pathogenic strains of $E$ coli and Salmonella enterica $[24,25]$. There are many factors that can influence the virulence and human pathogenicity of microorganisms. These include, for example, the formation of certain adhesion molecules that bind to host cells, such as adhesins of bacterial pili. In addition, secretion systems containing multiple proteins that are transferred from pathogens to the host cells help pathogens invade these cells. Pathogens may also produce enzymes and toxins that cause damage in host cells, which may facilitate entry into tissues (eg, proteinases of fungi infecting lungs) or suppress immune response (eg, damage to blood cells). In addition, pathogens may be selfsufficient for certain nutritional compounds or be able to sequester them, such as by producing siderophores that complex with iron. Other common characteristics are quorum sensing by "autoinducing" substances, the regulation of expression of pathogenicity-associated genes at the appropriate stage of infection, formation of capsules, and the ability of fungi to change their morphology. These and other aspects that influence the pathogenicity of microorganisms are reviewed elsewhere in more detail (eg, $[26,27])$.

The source, function, and characteristics of transgenes and derived products, which may or may not be associated with pathogenicity, are commonly considered during the safety assessment of GM crops. While the assessment in practice may also include the potential horizontal transfer of pathogenicity-associated transgenes, such as required by the EU [28], this issue is not explicitly mentioned in the previously mentioned FAO/WHO Codex Alimentarius guidelines, which focus solely on the transfer of antibiotic-resistance genes.

\section{Scope of this study}

In this article, we discuss the characteristics of transgenes of microbial origin that have been introduced into GM crops that have received regulatory approvals for food use. The reason for limiting the survey to transgenes of microbial origin is because they are the most likely to be transferred to microorganisms based on the following considerations. As stated above, homologous recombination between transgenes from GM crops and genes present in microbes is the most probable mechanism for horizontal gene transfer. This implies that similar sequences should already be present in the microorganisms before transfer can occur. Genetic modification allows for the introduction of DNA from unrelated species, including microbes, into crops. Indeed, a number of coding sequences of microbial origin have been introduced into various commercially approved GM crops (Table 1). The original nucleotide composition of these genes may have been optimised in some cases for expression in plants, due to differences, for example, in codon preference between bacteria and plants. In addition, plant-specific promoter and terminator sequences, as well as other sequences (introns, transition peptides) may have been introduced with the transgene to facilitate gene expression in plants.

The following issues are addressed for each transgene:

(i) microbial source of the gene, including occurrence and pathogenicity of the microorganism from which the gene originates;

(ii) natural function, such as the role that the gene product has in its native host;

(iii) natural prevalence of the gene in microorganisms other than the gene source;

(iv) geographical distribution, that is, the geographical locations where the gene and the microbial species that harbor it occur;

(v) similarity of the DNA of the transgene construct to other naturally occurring microbial genes, that is, a FASTA analysis has been performed to search for microbial analogues of

(1) the gene from its microbial source,

(2) the codon-modified transgene version introduced into GM crops;

(vi) known horizontal gene transfer activity of the gene; among others, the location of the native microbial transgene on chromosome, plasmid, or phage is considered, since this might predispose the gene to transfer, for example, through conjugation (plasmid) or transduction (phage); in addition, data that indicate that transfer might have occurred are also considered;

(vii) selective conditions and environments for bacteria carrying horizontally acquired genes;

(viii) potential of the transgene to cause microbial pathogenicity or to increase virulence;

(ix) conclusion: based on the data considered for each gene, we conclude on whether horizontal gene transfer of the transgene in GM crops to microorganisms would be likely to cause or aggrevate any adverse health effects in consumers.

The FASTA analysis in search for microbial genes that are similar to the transgenes served two purposes. First, the occurrence of analogues in other microbes might indicate the extent of the dispersal of the native transgene in species. Second, the results help to identify which of these analogues are amenable to homologous recombination. For homologous recombination to occur, matching segments should have a minimal length. For example, identical flanking segments of at least $20 \mathrm{bp}$ are required to 
TABLE 1. Microbial transgenes in GM crops that have been approved for human food use $\mathrm{e}^{\mathrm{a}, \mathrm{b}, \mathrm{c}}$.

\begin{tabular}{|c|c|c|c|}
\hline Transgene product & Origin & Trait & Nation $^{\mathrm{d}}$ \\
\hline \multicolumn{4}{|l|}{ Herbicide resistance } \\
\hline Bromoxynil nitrilase & Klebsiella pneumonia ozaenae & Bromoxynil resistance & AUS-NZ, CAN, USA \\
\hline $\begin{array}{l}\text { Enolpyruvylshikimate phosphate } \\
\text { synthase }\end{array}$ & Agrobacterium $\mathrm{CP} 4$ & Glyphosate resistance & AUS-NZ, CAN, EU, USA \\
\hline Glyphosate oxidoreductase & Achromobacter LBAA & Glyphosate resistance & AUS-NZ, CAN, EU, USA \\
\hline $\begin{array}{l}\text { Phosphinothricin acetyltransferase } \\
\text { (bar) }\end{array}$ & Streptomyces hygroscopicus & Glufosinate resistance & AUS-NZ, CAN, EU, USA \\
\hline $\begin{array}{l}\text { Phosphinothricin acetyltransferase } \\
\text { (pat) }\end{array}$ & Streptomyces viridochromogenes & Glufosinate resistance & AUS-NZ, CAN, EU, USA \\
\hline \multicolumn{4}{|l|}{ Male sterility and fertility restoration } \\
\hline$\overline{\text { Barnase }}$ & Bacillus amyloliquefaciens & Male sterility & AUS-NZ, CAN, EU, USA \\
\hline Barstar & Bacillus amyloliquefaciens & Fertility restorer & AUS-NZ, CAN, EU, USA \\
\hline DNA adenine methylase & Escherichia coli & Male sterility & USA \\
\hline \multicolumn{4}{|l|}{ Plant hormone metabolism } \\
\hline $\begin{array}{l}\text { Aminocyclopropane-carboxylate } \\
\text { deaminase }\end{array}$ & Pseudomonas 6G5 & Prolonged ripening & USA \\
\hline S-adenosylmethionine hydrolase & $\begin{array}{l}\text { Escherichia coli bacteriophage } \\
\text { T3 }\end{array}$ & Prolonged ripening & USA \\
\hline \multicolumn{4}{|l|}{ Transformation marker } \\
\hline Beta glucuronidase (uidA) & Escherichia coli & Colour reaction & AUS-NZ, CAN, USA \\
\hline Nopaline synthase & $\begin{array}{l}\text { Agrobacterium tumefaciens } \\
\text { pTiC58 }\end{array}$ & Nopaline synthesis & CAN, USA \\
\hline \multicolumn{4}{|l|}{ Insecticidal proteins } \\
\hline$\overline{\text { Crystal protein Cryl }} \mathrm{Ab}$ & Bacillus thuringiensis kurstaki & Insect resistance & AUS-NZ, CAN, EU, USA \\
\hline Crystal protein Cry1Ac & Bacillus thuringiensis kurstaki & Insect resistance & AUS-NZ, CAN, EU, USA \\
\hline Crystal protein Cry1Fa & Bacillus thuringiensis aizawai & Insect resistance & AUS-NZ, CAN, USA \\
\hline Crystal protein Cry2Aa & Bacillus thuringiensis kurstaki & Insect resistance & AUS-NZ \\
\hline Crystal protein Cry $2 \mathrm{Ab}$ & Bacillus thuringiensis kurstaki & Insect resistance & AUS-NZ, CAN, USA \\
\hline Crystal protein Cry3Aa & Bacillus thuringiensis tenebrionis & Insect resistance & AUS-NZ, CAN, USA \\
\hline Crystal protein Cry3Bb & Bacillus thuringiensis EG4961 & Insect resistance & AUS-NZ, CAN, USA \\
\hline Crystal proteins Cry34Ab, Cry35Ab & Bacillus thuringiensis PS149B1 & Insect resistance & USA \\
\hline
\end{tabular}

${ }^{a}$ Antibiotic-resistance marker genes are not included.

bSources of information: [29, 30, 31, 32].

'The American Food and Drug Administration (FDA) does not formally approve GM foods; "USA" in the fourth column indicates that the particular transgene is present in GM crops for which a consultation with the FDA has been completed.

dAUS-NZ, Australia-New Zealand; CAN, Canada; EU, European Union; USA, United States of America.

insert DNA by homologous recombination in Escherichia coli $[33,34]$, such that the minimal length would correspond to $2 \times 20 \mathrm{bp}$. It should be noted that this represents a minimum requirement and that longer segments of identical nucleotides will have an increased likelihood of recombining. In addition, the presence of shorter identical segments $(<20 \mathrm{bp})$ in the DNA surrounding the recombination site facilitates complex formation with the incoming DNA, thereby increasing the efficiency of the subsequent recombination (eg, [35]). Therefore, the occurrence of both a high overall similarity and identical stretches above a particular length indicates an increased probability of homologous recombination with the transgene. Given that in many cases the native sequences and not the plant-optimised transgenic sequences have been used for the FASTA analysis, the outcomes may represent a "worst-case" scenario.
The FASTA analysis, which compared the transgene with microbial genes, was carried out using the EBI website's FASTA facility with default settings being used. More specifically, the sequences of interest were compared with the EBI's sub-databases with nucleotide sequences derived from prokaryotes, bacteriophages, and fungi (European Bioinformatics Institute's nucleic acid database, http://www.ebi.ac.uk/fasta 33/nucleotide.html). From the results, sequences from microorganisms that showed similarity with the sequence of interest and that did not belong to the same species as the gene source were considered. Of these sequences, those were identified that complied with one or both of two criteria. The first criterion is an expectation (E) value of $1^{*} 10^{-30}$ at maximum, which is a statistical term indicating the likelihood that an alignment with the same similarity score would occur by chance within the chosen database [36]. This arbitrarily 
chosen $\mathrm{E}$ value is stringent and therefore corresponds to a high degree of similarity between aligned sequences. The other criterion is identical nucleotide stretches of minimally twice 20 nucleotides $(2 \times 20 \mathrm{bp})$ required for homologous recombination, as explained above.

In a similar fashion, another review that has recently been published dealt with the microbial transgenes and sequences present in GM crops and the significance of their transfer to soil bacteria [37].

\section{OVERVIEW OF TRANSGENES AND THEIR CHARACTERISTICS}

\section{Bromoxynil nitrilase (BXN) \\ Microbial source}

The bxn gene used for genetic modification of crops has been cloned from an isolate of the bacterium Klebsiella pneumonia var ozaenae found in bromoxynilcontaminated soil. This isolate was capable of growing on bromoxynil-containing media and utilising the ammonia released from converted bromoxynil as its sole source of nitrogen $[38,39]$.

\section{Natural function}

Bromoxynil nitrilase (BXN) converts the cyano (nitrile, $\mathrm{CN}$ )-moiety of the bromoxynil molecule to a carboxyl (COOH)-moiety. Conversion of bromoxynil by nitrilase enzymes from other microorganisms is much less efficient. The Klebsiella BXN displays substrate specificity towards aromatic molecules that have halogen substituents in the meta positions with respect to the cyano moiety [40].

A putative function of these nitrile-degrading enzymes in conjunction with aldoxime dehydratase enzymes is the degradation of plant-produced aldoxime compounds by soil microorganisms [41].

\section{Function in GM crops}

Genetic engineering of BXN into crop plants renders them resistant to application of the herbicide bromoxynil [39].

\section{Natural prevalence}

In a broader perspective, nitrilases occur in a range of microorganisms and plants. Also other related enzymes convert nitriles, such as NHases and amidases [42, 43]. Phylogenetic analysis revealed that $\mathrm{BXN}$ is closely related to fungal cyanide hydratase enzymes, which convert nitriles to amides [43]. The nitrile-metabolising capacity of some microorganisms is currently exploited in industrial processes, like the production of acrylamide from acrylonitrile $[42,43]$.

\section{Geographical distribution}

A recent study reports the presence of nitriledegrading activity in bacteria and actinomycetes from soil and deep-sea samples of wide-ranging geographical origins. For example, bromoxynil-metabolising, gramnegative bacteria were detected in soil samples from Argentina and Namibia [44].

\section{Similarity to other microbial genes}

The native gene sequence used for FASTA analysis was derived from K pneumoniae var ozaenae, accession J03196 [45], with a coding sequence size of $1050 \mathrm{bp}$. No similarities corresponding to the threshold criteria were observed (Table 2). The codon-modified transgene sequence of $b x n$, as has been introduced into GM crops, was not available for FASTA analysis.

\section{Known horizontal gene transfer activity}

The $b x n$ gene is located on an $82-\mathrm{kDa}$ plasmid in $K$ pneumoniae var ozaenae [46]. After artificial transfer to E coli, this plasmid was found to be stably maintained in cells grown in the presence of bromoxynil. However, in the absence of bromoxynil, a 14-kDa deletion of the plasmid with concurrent loss of $b x n$ was observed. This deletion was probably recA-dependent [46]. There was no information available regarding the horizontal transfer of the bxn gene.

\section{Selective conditions and environments}

As stated above, soil bacteria harbouring the bxn gene were able to utilize bromoxynil as the sole nitrogen source. Furthermore, after artificial transfer to $E$ coli, the native plasmid harbouring the bxn gene was stably maintained in the presence of bromoxynil, whereas a fragment containing the $b x n$ gene was deleted in the absence of bromoxynil. In addition, its putative natural function is the metabolism of plant-secreted aldoxime compounds. We therefore conclude that, in theory, bacteria carrying an active $b x n$ gene would have a selective advantage in soils, such as crop land, to which the herbicide bromoxynil is applied, or in the vicinity of plants secreting aldoxime compounds.

\section{Potential for pathogenicity or virulence}

K pneumonia var ozaenae, the source of the bxn gene, is synonymous to Klebsiella ozaenae. This bacterium is also known as a human pathogen associated with "ozena" (atrophic rhinitis, an affection of the upper respiratory tract), as well as with other affections, such as bacteremia and urinary tract infection [47]. No information was available on the role that BXN might have in the pathogenicity of its gene source, K pneumonia var ozaenae. 
TABLE 2. Similarity of native microbial transgenes to other microbial sequences.

\begin{tabular}{|c|c|c|c|}
\hline Native gene $\mathrm{a}^{\mathrm{a}}$ & Similarity & Microorganism & Gene accession $^{\mathrm{b}}$ \\
\hline$b x n$ & No & & \\
\hline \multirow[t]{12}{*}{ cp4 epsps } & $\mathrm{E}<1^{*} 10^{-30}$ and $2 \times 20 \mathrm{bp}$ & Brucella melitensis & AE009625; AF326475 \\
\hline & & Brucella suis & $\mathrm{AE} 014291^{\mathrm{c}}$ \\
\hline & & Mesorhizobium loti & BA000012 \\
\hline & & Sinorhizobium meliloti & AL591783c \\
\hline & $\overline{\mathrm{E}<1^{*} 10^{-30}}$ & Bartonella henselae & BX897699 \\
\hline & & Bartonella quintana & BX897700 \\
\hline & & Bradyrhizobium japonicum & BA000040 ${ }^{\mathrm{c}}$ \\
\hline & & Caulobacter crescentus & $\mathrm{AE} 006017^{\mathrm{c}}$ \\
\hline & & Gluconobacter oxydans, & СР000009 \\
\hline & & Rhodopseudomonas palustris & BX572593c \\
\hline & & Silicibacter pomeroyi & СР000032 \\
\hline & & Zymomonas mobilis & AE008692 \\
\hline gox & No & & \\
\hline bar & $\mathrm{E}<1^{*} 10^{-30}$ and $2 \times 20 \mathrm{bp}$ & $\begin{array}{l}\text { Streptomyces } \\
\text { viridochromogenes }\end{array}$ & X65195; M22827 \\
\hline pat & $\mathrm{E}<1^{*} 10^{-30}$ and $2 \times 20 \mathrm{bp}$ & Streptomyces hygroscopicus & X05822; X17220 \\
\hline \multirow[t]{5}{*}{ barnase } & $\mathrm{E}<1^{*} 10^{-30}$ and $2 \times 20 \mathrm{bp}$ & Bacillus circulans & Z29626 \\
\hline & $\overline{\mathrm{E}<1^{*} 10^{-30}}$ & Bacillus intermedius & X53697 \\
\hline & & Bacillus licheniformis & $\mathrm{AE} 017333^{\mathrm{c}} ; \mathrm{CP} 000002^{\mathrm{c}}$ \\
\hline & & Bacillus pumilus & U06867 \\
\hline & $2 \times 20 \mathrm{bp}$ & B intermedius & AJ006407 \\
\hline barstar & No & & \\
\hline \multirow{19}{*}{ dam } & $\mathrm{E}<1^{*} 10^{-30}$ and $2 \times 20 \mathrm{bp}$ & Salmonella enterica & AL627281; AE016847 \\
\hline & & Salmonella typhimurium & AE008860; U76993 \\
\hline & & Shigella flexneri & AE016992 \\
\hline & $\mathrm{E}<1^{*} 10^{-30}$ & Actinobacillus actinomycetemcomitans & AF263926 \\
\hline & & Erwinia carotovora & BX950851 \\
\hline & & Haemophilus influenzae & $\mathrm{U} 32705^{\mathrm{c}}$ \\
\hline & & Legionella pneumophila & AE017354 \\
\hline & & Mannheimia succiniciproducens & AE016827 \\
\hline & & Neisseria meningitidis & AF091142 \\
\hline & & Pasteurella multocida & AE006162; AF411317 \\
\hline & & Photobacterium profundum & CR378663c \\
\hline & & Photorhabdus luminescens & BX571859 \\
\hline & & Serratia marcescens & X78412 \\
\hline & & Shewanella oneidensis & $\mathrm{AE} 015477^{\mathrm{c}}$ \\
\hline & & Vibrio cholerae & AE004329'; AF274317; AY341955 \\
\hline & & Vibrio parahaemolyticus & BA000031 \\
\hline & & Vibrio vulnificus & BA000037; AE016801 \\
\hline & & Yersinia pestis & AJ414141; AE017127; AE013998 \\
\hline & & Yersinia pseudotuberculosis & BX936398с ; AF274318 \\
\hline \multirow[t]{13}{*}{ ACC deaminase } & $\mathrm{E}<1^{*} 10^{-30}$ and $2 \times 20 \mathrm{bp}$ & Achromobacter xylosoxidans & AY604539d \\
\hline & & Burkholderia mallei & $\mathrm{CP} 000011^{\mathrm{c}}$ \\
\hline & & Burkholderia pseudomallei & BX571966 \\
\hline & & Enterobacter cloacae & AF047840; AF047710 \\
\hline & & Pseudomonas fluorescens & U37103 \\
\hline & & Pseudomonas brassicacearum & AY604528d \\
\hline & & Ralstonia solanacearum & AL646080 \\
\hline & & Variovorax paradoxus & AY604531 \\
\hline & $\overline{\mathrm{E}<1^{*} 10^{-30}}$ & Acidovorax facilis & AY604529d \\
\hline & & Agrobacterium tumefaciens & $\mathrm{AF} 315580^{\mathrm{c}}$ \\
\hline & & Bradyrhizobium japonicum & BA000040 \\
\hline & & Mesorhizobium loti & AL672114c; BA000012 \\
\hline & & Penicillium citrinum & $\mathrm{AB} 038511$ \\
\hline
\end{tabular}


Table 2. Continued.

\begin{tabular}{|c|c|c|c|}
\hline Native gene $^{\mathrm{a}}$ & Similarity & Microorganism & Gene accession $^{\mathrm{b}}$ \\
\hline & & Pseudomonas sp & M73488 \\
\hline & & Pseudomonas putida & AY604533 ${ }^{d}$ \\
\hline & & Pseudomonas syringae & $\mathrm{AE} 016869^{\mathrm{c}}$ \\
\hline & & Rhizobium leguminosarum & AF421376; AY604535 ${ }^{\mathrm{d}}$ \\
\hline & & Rhizobium sullae & AY $604534^{d}$ \\
\hline & & Rhodococcus sp & AY604538d ${ }^{d}$ AY604537 \\
\hline & & Schizosaccharomyces pombe & AL133522 \\
\hline & & Variovorax paradoxus & AY604530d ${ }^{\mathrm{d}}$ AY604532 ${ }^{\mathrm{d}}$ \\
\hline SAMase & $\mathrm{E}<1^{*} 10^{-30}$ and $2 \times 20 \mathrm{bp}$ & Bacteriophage phiYeO3-12 & AJ251805 \\
\hline \multirow[t]{7}{*}{ uidA } & \multirow[t]{5}{*}{$\mathrm{E}<1^{*} 10^{-30}$ and $2 \times 20 \mathrm{bp}$} & Shigella sp & AY698518 $;$ AY698517 \\
\hline & & Shigella boydii & 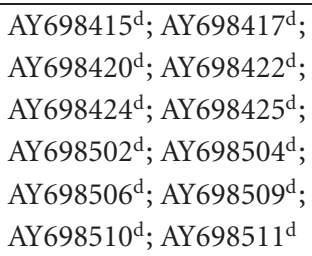 \\
\hline & & Shigella dysenteriae & 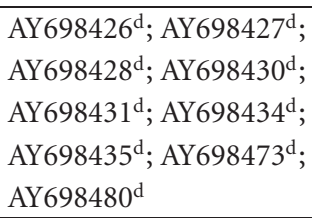 \\
\hline & & Shigella flexneri & 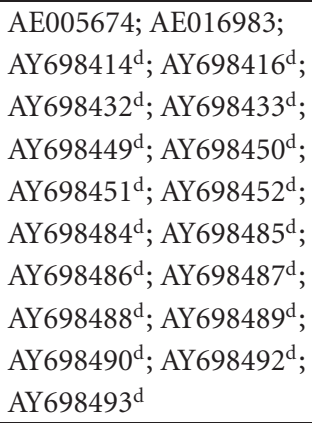 \\
\hline & & Shigella sonnei & 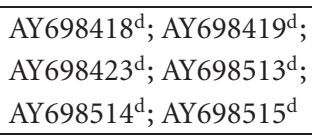 \\
\hline & \multirow[t]{2}{*}{$\mathrm{E}<1^{*} 10^{-30}$} & Penicillium canescens & $\mathrm{AY773333}^{\mathrm{c}} ; \mathrm{AY} 773334$ \\
\hline & & Scopulariopsis sp & AY773335 \\
\hline nos & $\mathrm{E}<1^{*} 10^{-30}$ and $2 \times 20 \mathrm{bp}$ & Agrobacterium vitis plasmid pTiAB4 & X77327 \\
\hline$c r y^{\mathrm{e}}$ & No & & \\
\hline
\end{tabular}

a "Native gene" means the native sequence from the microbial source of the transgene without codons modified. One codon-modified transgene, $c p 4$ epsps, that has been introduced into GM crops has been analysed by FASTA, of which the results are summarised in Table 3. Coding sequences were submitted to a FASTA search using default settings against the EMBL nucleotide databases for prokaryotes, bacteriophages, and fungi. The similarity thresholds applied were $\mathrm{E}<1^{*} 10^{-30}$ and/or $2 \times 20 \mathrm{bp}$. Results for genes from the same microbial species as the gene source are not listed. Abbreviations: ACC deaminase, 1-aminocyclopropane-1-carboxylate deaminase; bar, phosphinothricin acetyltransferase; bxn, bromoxynil nitrilase; cp4 epsps, CP4 3-enolpyruvylshikimate-5-phosphate synthase; cry, crystalline insecticidal protein; dam, DNA adenine methylase; gox, glyphosate oxidoreductase; nos, nopaline synthase; pat, phosphinothricin acetyltransferase; SAMase, S-adenosylmethionine hydrolase; uidA, $\beta$-glucuronidase. ${ }^{b}$ Nucleotide accessions can be retrieved from the NCBI website [45].

${ }^{\mathrm{c}}$ Putative function assigned to gene.

dPartial coding sequence.

${ }^{\text {e}}$ Details on the individual cry genes tested and their accessions are provided in Table 4 . In some of the genes, the coding sequences had been truncated in analogy to the truncation of transgenes used for genetic modification of crops. For cry $1 \mathrm{Ab}$, the first 1944 nucleotides were used, corresponding to a protein sequence of 648 amino acids. The truncated sequence of crylFa comprised the first 1815 nucleotides (605 amino acids). Full-length coding sequences were used for $c r y 1 A c$ (3537 bp), cry2Aa (1902 bp), cry2Ab (1902 bp), cry3Aa (1935 bp), cry3Bb (1959 bp), cry34Ab (372 bp), and cry35Ab (1152 bp). 
TABLE 3. Similarities of the codon-modified cp4 epsps transgene introduced into herbicide-resistant GM soybean to microbial genes.

\begin{tabular}{|c|c|c|c|}
\hline Transgene $^{\mathrm{a}}$ & Similarity & Microorganism & Gene accession $^{b}$ \\
\hline \multirow[t]{9}{*}{ cp4 epsps } & $\mathrm{E}<1^{*} 10^{-30}$ and $2 \times 20 \mathrm{bp}$ & Brucella melitensis & AE009625; AF326475 \\
\hline & & Brucella suis & AE014291 \\
\hline & & Mesorhizobium loti & BA000012 \\
\hline & & Sinorhizobium meliloti & AL591783c \\
\hline & $\mathrm{E}<1^{*} 10^{-30}$ & Bartonella henselae & BX897699 \\
\hline & & Bartonella quintana & BX897700 \\
\hline & & Bradyrhizobium japonicum & BA000040 \\
\hline & & Caulobacter crescentus & $\mathrm{AE} 006017^{\mathrm{c}}$ \\
\hline & & Rhodopseudomonas palustris & BX572593 \\
\hline
\end{tabular}

a,b,c See legend to Table 2 .

\section{Conclusion}

BXN activity is highly substrate-specific and the putative function relates to plant compound degradation. Even though the bxn gene is derived from a potential human pathogen, no direct impact of this gene on human or animal health is foreseen if it were to be transferred to pathogens given the apparently specific role of this gene in soil environments.

\section{3-enolpyruvylshikimate-5-phosphate synthase (cp4 EPSPS) \\ Microbial source}

The source of the cp4 epsps gene was the soil bacterium Agrobacterium strain CP4, which was one out of a group of glyphosate-degrading bacteria (reviewed in [48]). Bacterial species of the genus Agrobacterium are all characterised by the ability to form neoplastic lesions in plants (eg, [49]).

\section{Natural function}

The 3-enolpyruvylshikimate-5-phosphate synthase (EPSPS) enzyme catalyses an intermediate step in the shikimate pathway for the synthesis of essential aromatic precursor compounds of, among others, aromatic amino acids and lignin, which is part of lignocellulose plant fibres. EPSPS enzymes, also called AroA enzymes, occur in a wide variety of organisms (eg, bacteria, fungi, plants). EPSPS enzymes in plants are targets for the herbicide active ingredient glyphosate, which binds and inhibits the plant EPSPS enzymes. The EPSPS enzyme from Agrobacterium $\mathrm{CP} 4$, however, is not sensitive towards the action of glyphosate (reviewed in [48]).

\section{Function in GM crops}

A number of commercialised GM crops contain the cp4 epsps gene coding for the enolpyruvylshikimatephosphate synthetase (EPSPS) enzyme from Agrobacterium strain $\mathrm{CP} 4$, which confers resistance towards the otherwise lethal herbicide glyphosate [48].

\section{Natural prevalence}

The amino acid sequences of EPSPS enzymes from various species present in food (soybean, maize, E coli, $B$ subtilis, Saccharomyces cerevisiae) are divergent and the identities that they share with the sequence of Agrobacterium CP4 EPSPS range from 24.1 to 41.1 percent [48]. Because of its relative insensitivity towards the inhibiting action of glyphosate, the Agrobacterium CP4 EPSPS enzyme has been engineered into a number of crops to make them glyphosate-resistant [48].

\section{Geographical distribution}

The geographical distribution of the cp4 epsps gene and its source, Agrobacterium CP4, has not been specifically reported in literature. More generally, Agrobacterium species occur globally in soils, for example, in the rhizosphere of plants (eg, [50]).

\section{Similarity to other microbial genes}

The coding sequence of the native cp4 epsps gene (Agrobacterium CP4, accession I43998 [45], size 1368 bp) was used for FASTA analysis. The search results in Table 2 show that a number of bacterial aroa genes show a high degree of similarity to the epsps transgene. These aroa genes are from Bradyrhizobium japonicum, Caulobacter crescens, Gluconobacter oxydans, Mesorhizobium loti, Rhodopseudomonas palustris, Silicibacter pomeroyi, Sinorhizobium meliloti, and Zymomonas mobilis, as well as of the pathogenic bacteria Bartonella quintana, Bartonella henselae, Brucella melitensis, B melitensis biovar abortus, and Brucella suis. The observed identities probably relate to phylogenetic relationship, such as observed between the genome of $B$ suis and sequences of $A$ tumefaciens, $B$ melitensis, $M$ loti, and $S$ meliloti $[51,52]$, as well as between $B$ henselae, $B$ melitensis, and $B$ quintana [53]. The aroa genes of Brucella melitensis, B melitensis biovar abortus, Brucella suis, Mesorhizobium loti, and Sinorhizobium meliloti shared identical DNA stretches of at least twice $20 \mathrm{bp}$ with the transgenic sequence, which is considered the minimum required for homologous recombination (Table 2). 
TABLE 4. cry transgenes present in GM crops that have been approved for food use.

\begin{tabular}{lllll}
\hline Gene & Target pest, class & $\begin{array}{l}\text { Gene source, } \\
\text { B thuringiensis } \\
\text { subspecies }\end{array}$ & Genbank accession ${ }^{\mathrm{a}}$ & Reference \\
\hline cry1ab & Lepidopterans & Kurstaki & M15271 & {$[159]$} \\
cry1ac & Lepidopterans & Kurstaki & M11068 & {$[160]$} \\
crylfa & Lepidopterans & Aizawai & M63897 & {$[161]$} \\
cry2aa & Lepidopterans & Kurstaki & M31738 & {$[162]$} \\
cry3ab & Lepidopterans & Kurstaki & X55416 & {$[163]$} \\
cry3bb & Coleopterans & Tenebrionis & M30503 & {$[164]$} \\
cry34ab and cry35ab & Coleopterans & EG4961 & M89794 & {$[165]$} \\
\hline
\end{tabular}

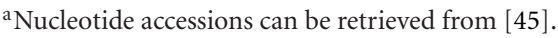

The sequence of the epsps transgene in GM soybean has been described in literature [54]. The coding sequence of this transgene was used for FASTA analysis (accession AY125353 [45], size $1368 \mathrm{bp}$ ). The results were largely similar to those with the native gene (see above), except for the fact that the aroa genes from $G$ oxydans, $S$ pomeroyi, and $Z$ mobilis did not score sufficiently with respect to the threshold values $\left(\mathrm{E}<1^{*} 10^{-30} ; 2 \times 20 \mathrm{bp}\right.$; Table 3).

\section{Known horizontal gene transfer activity}

With regard to the location of the native gene within the genome, the cp4 epsps gene has been isolated from chromosomal DNA of Agrobacterium CP4 [55]. No information was found on the natural horizontal transfer of aroa or epsps genes. Netherwood et al reported the detection of the cp4 epsps gene in bacteria isolated from small intestines of ileostomic patients who had consumed transgenic soy, but not in bacteria from feces of healthy subjects. These authors were, however, unable to cultivate the bacteria with the transferred transgenes, preempting a further confirmation of their results [20].

\section{Selective conditions and environments}

No specific information was available on the selective advantage of the cp4 epsps transgene to microorganisms. As previously mentioned, this gene was isolated from a soil bacterium that was able to degrade glyphosate. It is therefore conceivable in our view that the transfer of the cp4 epsps sequence would convey a selective advantage to microorganisms in glyphosate-treated soil, that is, the ability to sustain glyphosate toxicity and to utilise it as a substrate.

\section{Potential for pathogenicity or virulence}

The aroa gene, which codes for EPSPS, is considered a factor that influences the virulence of a number of pathogenic microorganisms. Pathogenic bacteria with either defective or without aroa genes (ie, aroa $^{-}$mutants) are unable to produce aromatic intermediates and therefore are auxotrophic, that is, dependent upon the supply of aromatic substrates, such para-aminobenzoic acid. Because humans and animals do not produce aromatic precursors, the rroa $^{-}$mutants of pathogens are unable to multiply in their bodies.

Aroa $^{-}$mutants of a number of pathogenic microorganisms have been developed as candidates for live "attenuated," avirulent vaccines. For example, aroa $^{-}$mutants of Salmonella typhimurium and other Salmonella species are well described in literature, also in combination with other mutations (such as for adenine nucleotides) that impact on virulence. While these mutants have been successfully tested as oral vaccines against $S$ typhimurium, for example, in laboratory and domestic animals, they may also serve as vehicle for transgenic protein antigens in recombinant vaccines, or for transgenic DNA in DNA vaccines. These vaccines exploit the mutants' retained capacity of $S$ typhimurium to enter the host's immune system from the intestines, and thereby prime this system against the antigens of interest (see, for review, $[56,57]$ ).

In addition, the aroa genes of Pasteurella haemolytica, Pasteurella multocida, Haemophilus somnus, and Aeromonas salmonicida have been mutated in precommercial attenuated live vaccines for cattle, poultry, and fish, as reported in scientific literature [58] and secondary information sources $[59,60,61]$.

Reversion of auxotrophy in mutants by restoration of aroa by horizontal transfer of transgenes would, in theory, confer a selective advantage to the recipient.

In the FASTA analysis with the cp4 epsps genes present in Agrobacterium CP4 and GM soybean, aroa genes from Brucella showed a high similarity, including identical nucleotide stretches of at least $2 \times 20 \mathrm{bp}$. Because Brucella is an intracellular pathogen like Salmonella, it may be suitable for development as attenuated live vaccine or vaccine carrier. Defective aromatic amino acid biosynthesis has been associated with attenuation of Brucella, such as in an aro $C$ mutant of $B$ suis [62] and an auxotrophic strain of Brucella abortus [63]. There are currently no reports, however, of specific aroa $a^{-}$mutants of $B$ suis or B melitensis as candidate attenuated oral vaccines. 


\section{Conclusion}

There is a widespread occurrence of EPSPS in nature, which relates to its role as a "household" enzyme in many organisms. With regard to mutated aroa genes of aroa $^{-}$ oral vaccines, repair by homologous recombination of these genes with the cp4 epsps transgene appears unlikely given the lack of sufficient similarity between them. In addition, glyphosate, towards which CP4 EPSPS is insensitive, does not have a role in treatment of human or animal disease. Therefore, we conclude that there is no indication that the potential transfer of the cp4 epsps gene from GM crops to microorganisms would alter the pathogenicity of the latter.

\section{Glyphosate oxidoreductase (GOX) Microbial source}

The source organism Achromobacter LBAA was one of the bacteria isolated from activated industrial and domestic sludge that were capable of degrading glyphosate [64].

\section{Natural function}

The enzyme glyphosate oxidoreductase (GOX) hydrolyzes the C-N bond of glyphosate yielding aminomethylphosphonic acid (AMPA) and glyoxylic acid. The sequence of GOX has been reported to be unique. Oxygen serves as a cosubstrate in the enzymatic reaction and a putative flavin binding site for the FAD cofactor has been identified at the N-terminus of GOX (reviewed in [48]).

\section{Function in GM crops}

GOX obtained from Achromobacter LBAA has been introduced into some GM-crops together with glyphosate-resistant EPSPS (see above) in order to make these crops glyphosate-resistant [48].

\section{Natural prevalence}

It has been widely observed that the soil microflora converts glyphosate to AMPA. A limited number of studies address the GOX activity, by which glyphosate is converted to AMPA and glyoxylic acid through lysis of the $\mathrm{C}-\mathrm{N}$ bond, within specific bacteria, such as from industrial activated sludge that has been exposed to glyphosate and byproducts of its production (eg, $[65,66]$ and references cited herein). However, Forlani et al [67] observed that bacteria isolated from soil were not capable of utilising glyphosate as sole $\mathrm{C}$ or $\mathrm{N}$ source and concluded that formation of AMPA should therefore be due to non-culturable bacteria. In addition, Dick and Quinn [68] observed that, unlike the lysis of the $\mathrm{C}-\mathrm{N}$ bond by GOX, isolated glyphosate-degrading soil microorganisms cleaved the C-P bond of glyphosate. While GOX-activity has been predominantly been observed in environments containing glyphosate, it has recently been demonstrated in a thermophilic Geobacillus, which unlikely had been exposed to glyphosate. The function of this GOX activity in absence of glyphosate is unknown [69].

\section{Geographical distribution}

We are not aware of reports describing the geographical dispersion of the gox genes. However, the occurrence of Achromobacter species in the environment has been reported to be widespread, for example, in Europe, Middle East, and Central America [70, 71, 72]. In addition, the formation of AMPA from glyphosate in glyphosatetreated soils has been reported in various regions, including, among others, Europe, North and South America $[73,74,75]$.

\section{Similarity to other microbial genes}

The sequence used for FASTA analysis was the coding sequence of the native gox gene from Achromobacter LBAA (sequence number 3, US patent 5776760 [64], size 1296 bp). No similarities that complied with the threshold criteria were found (Table 2). The sequence of the transgenic gox transgene introduced into GM crops was not available, however, and no FASTA analysis could thus be performed on this sequence.

\section{Selective conditions and environments}

No specific data about a possible selective advantage of the transfer of the gox gene for recipients were retrieved from literature. As stated above, the gox gene was obtained from a glyphosate-degrading bacterium that had likely been exposed to glyphosate. The transfer of the gox gene might, in our view, enable recipient microorganisms in theory to sustain the toxicity of glyphosate and to utilise it as a substrate.

\section{Known horizontal gene transfer activity}

Chromosomal DNA of Achromobacter LBAA has served as source for the gox transgene, indicating that the latter has a chromosomal location [64]. No information was found on the natural horizontal transfer of aroa or epsps genes.

\section{Potential for pathogenicity or virulence}

The gene source belonged to the Achromobacter species, which can, in rare cases, cause human disease, such as bacteremia due to $A$ xylosoxidans $[76,77]$. No data were available on the possible role of gox in pathogenicity or virulence of Achromobacter.

\section{Conclusion}

There is still uncertainty about the precise function of GOX in its natural environment in the absence of glyphosate. As discussed above, there is a background of widespread microbial GOX-like activity in soil. In addition, glyphosate, which is converted by GOX, has no role in the treatment of human and animal disease. Therefore, we consider it unlikely that the potential transfer of GOX from transgenic plants would exert a significant effect on the pathogenicity of recipient microorganisms. 


\section{Phosphinothricin acetyltransferase (PAT) Microbial source}

Streptomyces hygroscopicus (bar gene) and Streptomyces viridochromogenes (pat gene) are streptomycetes that occur in soil and that produce the natural herbicide bialaphos (phosphinothricin-alanine-alanine). After its release from bialaphos, phosphinothricin inhibits the enzyme glutamine synthase, which is important in nitrogen metabolism, in plants and microorganisms (eg, [78]). Another phosphinothricin-containing peptide is phosalacine, produced by the streptomycete Kitasatosporia phosalacinea [79]. In a more general sense, streptomycetes are soil microorganisms. The production of antibiotics, for example, streptomycin, and extracellular enzymes by streptomycetes is exploited on an industrial scale.

\section{Natural function}

Phosphinothricin $N$-acetyl transferase (PAT, encoded by bar and pat) inactivates phosphinothricin by acetylating the $\mathrm{NH}_{2}$ group. Besides the target substrate phosphinothricin, PAT also acetylates, to a lesser extent, demethyl-phosphinothricin (DMPT), methionine sulfoximine (MSO), hydroxylysine, and glutamate [80, 81, 82].

\section{Function in GM crops}

PAT has been engineered into a number of crops, conveying resistance against the herbicide glufosinate, a synthetic analogue of phosphinothricin. It serves either as a marker of genetic transformation or for the purpose of weed management in crops (see [80] and references herein).

\section{Natural prevalence}

The ability to detoxify phosphinothricin has been observed to be a prerequisite for its biosynthesis, so that this compound cannot become toxic to its producer $S$ hygroscopicus [83]. Wehrmann et al [80] mention that various acetyltransferases from Streptomyces griseus, Streptomyces coelicolor, and Alcaligenes faecalis are also capable of acetylating phosphinothricin with, however, comparatively weak affinity. In addition, Bedford et al [84] mention that such activity was also present in Streptomyces lividans.

\section{Geographical distribution}

To our knowledge, there are no reports describing the geographical distribution of the bar and pat genes. The sources of the bar and pat genes, $S$ hygroscopicus and $S$ viridochromogenes, belong to the streptomycetes, which are ubiquitously occurring soil microorganisms.

\section{Similarity to other microbial genes}

For the FASTA analysis, the coding sequences of the native genes of bar ( $S$ hygroscopicus, accession X05822 [45], size $552 \mathrm{bp}$ ) and pat (S viridochromogenes, M22827 [45], $552 \mathrm{bp}$ ) were used. These genes only shared with each other similarities that complied with the threshold criteria (Table 2). No FASTA analysis could be done on the codon-modified bar and pat transgene sequences present in GM crops, because they were unavailable.

\section{Known horizontal gene transfer activity}

The native genes of bar and pat isolated from S hygroscopicus and $S$ viridochromogenes, respectively, are chromosomally located $[85,86]$. No accounts are known of the horizontal transfer of the bar and pat genes from GM plants to microorganisms.

\section{Selective conditions and environments}

No information was available on the selective advantage that the introduction of PAT by horizontal transfer may have on recipient microorganisms. As mentioned above, the enzyme glutamine synthase, which is inhibited by phosphinothricin analogues like glufosinate, has an essential role in microorganisms. It is therefore conceivable in our view that microorganisms in environments containing glufosinate or other phosphinothricin analogues, such as in herbicide-treated soils, would benefit from PATinduced resistance against these compounds.

\section{Potential for pathogenicity or virulence}

With regard to the potential role of PAT in human pathogenicity and virulence of microorganisms, no information could be found.

\section{Conclusion}

PAT shows substrate specificity for phosphinothricin and similar compounds (see above). Whereas phosphinothricin is considered a natural antibiotic, it has no known application in the treatment of human and animal disease. We therefore conclude that the transfer of the PAT enzyme is unlikely to confer increased pathogenicity to pathogens.

\section{Barnase and Barstar Microbial source}

The genes encoding Barnase and Barstar have been cloned from Bacillus amyloliquefaciens. The first isolates of $B$ amyloliquefaciens obtained from soil produced high levels of extracellular $\alpha$-amylase, which distinguished these bacteria from Bacillus subtilis (Fukumoto, 1943, cited by [87]). This characteristic is exploited for industrial production of the $\alpha$-amylase enzyme.

\section{Natural function}

Barnase is a ribonuclease, which cleaves RNA yielding $3^{\prime}$ nucleotides through a $2^{\prime}, 3^{\prime}$-cyclic intermediate. Its structure displays a characteristic fold formed by an $\alpha$ helix and an antiparallel $\beta$-sheet. Barstar is the inhibitor of Barnase and both proteins form a one-to-one complex. The structures of both proteins and their complex have been the subject of study in many peer-reviewed articles $[88,89]$. 
It has been hypothesised that Barnase may either serve the utilisation of extracellular ribonucleotides or as a toxin for other microorganisms. By binding to Barnase, Barstar prevents $B$ amyloliquefaciens from damage before it secretes Barnase [89].

\section{Function in GM crops}

The ribonuclease Barnase from $B$ amyloliquefaciens has been cloned into some crops under control of a tapetum-specific promoter. The expression of this construct switches on specifically during anther development such that it impairs pollen formation and makes the crop male sterile. Male sterility is a useful trait for hybrid breeding and has also been obtained by non-GM breeding practices. Similar to GM crops expressing Barnase, "restorer" crop lines with tapetum-specific expression of Barstar have been developed. Crop fertility can be restored by crossing a male-sterile crop line transgenic for Barnase with a restorer line transgenic for Barstar [90].

\section{Natural prevalence}

Bacterial-, streptomycete-, and fungal-homologues of the Barnase ribonuclease from $B$ amyloliquefaciens have been identified, including Binase (Bacillus intermedius), St (Saccharopolyspora erythrea), T1 (Aspergillus oryzae), C2 (Aspergillus clavatus), Ms (Aspergillus saitoi), U1 and U2 (Ustilago sphaerogena; [88]). Several of the homologous fungal ribonucleases, for example, $\alpha$-sarcin, are part of a group of the so-called "ribotoxins." The function of these ribotoxins, as well as that of other Barnasehomologues, is not known. These ribonucleases all share the same three-dimensional "barnase-fold" structure as previously mentioned, with three conserved amino acid residues (Glu, Arg, His) that are involved in the catalytic reaction $[88,91]$.

In addition, homologues of Barstar have been found in the streptomycetes Streptomyces aureofaciens (Sai14) and $S$ erythrea (Sti), which inhibit the Sa- and Stribonucleases, respectively, produced by these organisms $[92,93]$.

\section{Geographical distribution}

No specific data are available on the geographical distribution of the occurrence of barnase and barstar genes and their microbial source, $B$ amyloliquefaciens.

\section{Similarity to other microbial genes}

The coding sequences of the native genes of barnase (B amyloliquefaciens, accession M14442 [45], size 450 bp) and barstar (B amyloliquefaciens, accession X15545 [45], size $273 \mathrm{bp}$ ) were used for FASTA analysis. Barnase showed high similarity to ribonuclease genes from other Bacillus species (Table 2). Barstar did not show similarities below the threshold $\mathrm{E}$ value $\left(\mathrm{E}<1^{*} 10^{-30}\right)$. The sequences of the codon-modified versions of these transgenes that are present in GM crops were not known, and therefore could not be analysed.

\section{Known horizontal gene transfer activity}

No information is provided on the location of the genes, that is, chromosomal or plasmid-bound, by the original reports that describe the isolation and cloning of the native barnase and barstar genes from $B$ amyloliquefaciens [94, 95]. Another report describes the PCR amplification of the barnase sequence located on a chromosomal fragment of $B$ amyloliquefaciens [96].

It has been suggested that the occurrence of ribonucleases with the characteristic barnase-fold in both prokaryotes and eukaryotes is indicative of either common ancestry or horizontal gene transfer [97]. The occurrence in a restricted number of organisms would indicate that these ribonucleases have recently evolved [91].

\section{Selective conditions and environments}

There were no observations reported of a possible selective advantage of the horizontal acquisition of the barnase and barstar genes. However, we estimate that if the role of barnase were to function as a toxin to other microorganisms, the barstar gene could convey a selective advantage to its recipients.

\section{Potential for pathogenicity or virulence}

Unlike Bacillus cereus, which can cause food poisoning, $B$ amyloliquefaciens, the source of the barnase and barstar transgenes, neither exerts toxicity on cultured cells nor produces enterotoxins, as reported in peer-reviewed literature and in a regulatory product evaluation $[98,99]$.

Extracellular ribonucleases other than Barnase are known to exert toxicity after cellular uptake, such as by binding to receptors on the surface of prokaryoticand human cells [100, 101]. Ribonuclease(ribotoxin)deficient mutants of Aspergillus fumigatus have been created by gene disruption through homologous recombination. Both wildtype and mutant strains were administered to mice through the inhalatory route. The animals were observed for mortality during the experiment and for fungal growth in lungs by postmortem histopathology. It was thus observed that ribotoxin-deficient fungi were no less pathogenic than wildtype strains in invasive Aspergillusmediated pulmonary infections (aspergillosis) [102]. Another study reported similar results [103]. Fungal ribonucleases therefore do not appear to have an important role in the pathogenicity of their hosts.

\section{Conclusion}

As stated above, B amyloliquefaciens, the source of the barnase and barstar genes, is not known to be a pathogen, unlike some other Bacillus species. However, the actual function of Barnase in its native host, including its potential role in pathogenicity and virulence, remains unclear. Barnase-related fungal ribonucleases do not appear 
to have a role in the pathogenicity of moulds, notwithstanding their toxicity to cells. Based on this circumstantial evidence, we conclude provisionally that the potential transfer of the barnase and barstar transgenes is unlikely to influence the pathogenicity of recipient microorganisms.

\section{DNA adenine methylase (DAM) Microbial source}

The dam gene has been isolated from Escherichia coli [104]. This bacterium is a common commensal intestinal microorganism, while pathogenic strains may occur. Pathogenic E coli strains can cause both intestinal and extraintestinal disease. For example, intestinal symptoms are caused by enteropathogenic (EPEC), enterotoxigenic (ETEC), enterohaemorrhegic (EHEC), or enteroinvasive (EIEC) E coli. Extraintestinal symptoms are caused, for example, by uropathogenic (UPEC) E coli. Meningitis is another example of an extraintestinal affection caused by particular strains of $E$ coli. Genes involved with virulence of pathogenic $E$ coli, such as those encoding adhesins, siderophores, and toxins, are linked with mobile genetic elements. These elements are not present in nonpathogenic strains and probably have been introduced by horizontal gene transfer [105].

\section{Natural function}

The DNA adenine methylase (DAM) enzyme regulates gene expression by methylation of adenine- $N^{6}$ within the DNA sequence GATC [106].

By methylation of the transcription initiation site where RNA polymerase binds, the expression of genes can either be stimulated or inhibited. In addition, methylation can also affect the binding of regulatory proteins to DNA [106]. More generally, DAM has also a role in DNA replication initiation and mismatch repair [107]. DAMactivity is associated with protection of bacteria against DNA damage, probably due to increased DNA breakage by intrinsic enzymes in the absence of dam, which predisposes DNA to further damage [108]. In addition, dam protects again membrane damage by bile acids in the intestinal environment, which probably relates to the role of dam in remodelling peptidoglycan, which can be part of the bacterial envelope [108, 109].

\section{Function in GM crops}

DAM has been introduced into GM crops in order to render them male-sterile, such as in maize approved for commercialisation in the USA [29] and in experimental maize [110]. In the commercialised maize, dam is said to be expressed only in the anthers [29].

\section{Natural prevalence}

DAM activity has been reported for other $\gamma$-proteobacteria besides $E$ coli and also, among others, in cyanobacteria, archaebacteria, and spirochetes [104, 111, 112].
In addition, adenine- $N^{6}$-methylating enzymes are encoded by bacteriophages, such as phage T4, which infects E coli [113].

\section{Geographical distribution}

No specific data were available on the geographical distribution of the native dam transgene. E coli has been isolated from a wide variety of geographical backgrounds, for example, from human and animal samples from different continents (eg, [114]).

\section{Similarity to other microbial genes}

The FASTA analysis was performed with the coding sequence of the native dam gene ( $E$ coli, accession J01600 [45], size $837 \mathrm{bp}$ ). The results showed that this sequence was present in the nonpathogenic $E$ coli strain $\mathrm{K}-12$, as well as in the enterohaemorrhagic strain O157:H7 and the uropathogenic strain CFT073 (results not shown). DAM genes occur in other bacteria with high sequence similarity to the native $E$ coli gene, indicating widespread occurrence of this essential gene (Table 2). The occurrence of many pathogenic bacteria among these results likely is accounted for by the fact that the genomes of a wide array of other $\gamma$-proteobacteria besides $E$ coli have been sequenced.

The sequence of the codon-optimised DNA of the dam transgene introduced into GM crops was not available. Therefore, no FASTA analysis could be performed on this sequence.

\section{Known horizontal gene transfer activity}

The dam transgene is located on the chromosome of $E$ coli [104]. The DNA sequences of the dam genes of $E$ coli and phage T4 have different AT-contents and are therefore not similar. Based on the fact that a number of amino acid residues appeared to have been conserved in the derived protein sequences of both genes, a common evolutionary origin was postulated [115].

Horizontal transfer, for example, by phage transduction, might restore the DAM activity within cells of damdeficient recipients. This has been shown with phage dam genes artificially cloned into $\mathrm{dam}^{-} \mathrm{E}$ coli, which repaired the methylation of plasmids by this bacterium (described, eg, by $[116,117])$.

\section{Selective conditions and environments}

As previously mentioned, DAM has a role in the protection of bacteria against damage to DNA and membranes in the intestinal environment [108]. The transfer of dam to intestinal bacteria deficient in this gene might therefore, in our opinion, confer a selective advantage, such as increased survivability.

\section{Potential for pathogenicity or virulence}

In pathogens like $S$ typhimurium, DAM has been shown to have an essential role in their virulence. Target sequences of DAM include multiple genes that are 
involved with the virulence of bacterial species, such as the gene encoding the toxin-coregulated pilus $(t c p)$ in uropathogenic $E$ coli, and DAM is therefore named a "masterswitch" of bacterial virulence (reviewed in [106]).

Avirulent DAM-deficient mutants of pathogenic bacteria have been described. While these avirulent mutants are able to induce an immune response, they are not as invasive as the wildtype pathogens and occur in much lower numbers in host tissues after oral administration, yet are able to prime an immune response against subsequent challenges with the wildtype pathogen. Reversion to virulence of $\mathrm{dam}^{-}$mutants by their transformation with functional dam genes has been observed in animal experiments [106].

The use of this technology for creating avirulent pathogens as live vaccines may be commercialised in the near future since the website of a biotechnology company offers DAM-deficient mutants for development of vaccines and vaccine carriers [118].

\section{Conclusion}

The dam transgene is derived from $E$ coli, which is a common resident of human intestines (eg, 8.0$8.7 \log \mathrm{cfu} / \mathrm{g}$ in fecal samples from positive infants [119]). In addition, native dam occurs in both pathogenic and nonpathogenic strains of $E$ coli, while counterparts with highly similar sequences occur widely in closely related $\gamma$-proteobacteria, as described above. To our knowledge, $\mathrm{dam}^{-}$live attenuated oral vaccines have not been commercialised yet. Therefore, we assume that, given the continuous background presence of natural counterparts, the potential transfer of the dam transgene would not impact on the pathogenicity of recipient microorganisms.

\section{1-aminocyclopropane-1-carboxylate (ACC) deaminase \\ Microbial source}

The gene encoding the 1-aminocyclopropane-1carboxylate (ACC) deaminase has been isolated from Pseudomonas 6G5. Out of 600 bacteria isolated from soil, this and another Pseudomonas bacterium showed ability to grow on minimal media containing ACC [120]. Members of the genus Pseudomonas belong to the $\gamma$ proteobacteria, and are ubiquitous and diverse, comprising strains that can be nonpathogenic or pathogenic to plants, animals, and humans. The pathogenic traits have been linked to the presence of genes that are absent from nonpathogenic Pseudomonas [121].

\section{Natural function}

The enzyme ACC deaminase from Pseudomonas 6G5 diverts ACC into ammonia and ketobutyric acid [120].

The plant hormone ethylene is formed from ACC in plants. Soil bacteria associated with roots of crops and plants have been found to express ACC deaminase activity. This activity suppresses the ethylene synthesis by plants and causes increased root formation by these crops (eg, [122]).

\section{Function in GM crops}

Introduction of the enzyme ACC deaminase into GM tomatoes prevents ethylene formation in fruits, which in turn delays fruit ripening [120].

\section{Natural prevalence}

The occurrence of ACC deaminase activity has been described in plant growth promoting soil bacteria, including strains of Alcaligenes, Bacillus, Enterobacter, Pseudomonas, Rhodococcus, Rhizobium, and Variovorax, as well as from the yeast Hansenula saturnus and the mould Penicillium citrinum $[122,123,124,125]$. Comparison of the amino acid sequences of ACC deaminase enzymes from bacteria, yeast, and mould shows a high degree of similarity and the conservation of residues that are essential for activity [126].

\section{Geographical distribution}

As stated above, the occurrence of bacteria of the genus Pseudomonas is ubiquitous [121]. ACC deaminasecontaining microbes can be found in soil samples from a wide range of origins, such as, for example, USA, Russia, a number of European countries, and Bhutan in Asia $[122,124,127]$. No data were available on the distribution of the ACC deaminase gene.

\section{Similarity to other microbial genes}

The coding sequence of the native ACC deaminase gene from Pseudomonas 6G5 was used for FASTA analysis (accession M80882 [45], size 1017 bp). This sequence showed high similarity with the corresponding genes from many soil bacteria species, as well as from the yeast Schizosaccharomyces pombe and the fungus Penicillium citrinum (Table 2). These similarities are in general agreement with the similarities reported in literature (see above). It was not possible to carry out the same analysis on the sequence of the codon-modified version of the $A C C$ deaminase transgene that had been introduced into GM crops, due to unavailability of this sequence.

\section{Known horizontal gene transfer activity}

The ACC deaminase gene was isolated from chromosomal DNA of Pseudomonas 6G5, indicating that it has a chromosomal position [120]. There were no accounts of the horizontal transfer of the ACC deaminase gene available in literature.

\section{Selective conditions and environments}

As previously mentioned, ACC deaminase allows its microbial hosts to utilise ACC as a sole N-source, which, in our view, would convey a selective advantage to microorganisms grown in the vicinity of plants, which produce ACC as an ethylene precursor. 


\section{Conclusion}

ACC deaminase is directed towards a plant hormone, which is not present in humans and animals. In addition, its gene from the gene source Pseudomonas 6G5 has similar counterparts in many related soil bacteria from a wide range of geographic origins, as well as in some eukaryotic microorganisms. We therefore conclude that the potential transfer of the ACC deaminase transgene from GM crops is unlikely to contribute to pathogenicity of recipient microorganisms.

\section{S-adenosylmethionine hydrolase (SAMase)}

\section{Microbial source}

The SAMase gene encoding the enzyme S-adenosylmethionine hydrolase (SAMase), as used for genetic modification, is derived from the E coli bacteriophage T3 [128].

\section{Natural function}

Hydrolysis of SAM by T3 SAMase yields 5 '-methylthioadenosine and homoserine [128].

The supposed function of native T3 SAMase is to inactivate the host's type I restriction endonuclease and to deplete its cofactor S-adenosylmethionine (SAM) in E coli cells infected by T3 [129]. This would protect the phage from being degraded by the host's DNA restriction activity.

In addition, artificial cloning of SAM hydrolase into bacteria like $E$ coli has been shown to reduce, among others, DNA methylation and biosynthesis of quorum sensing signaling molecules [130, 131, 132].

\section{Function in GM crops}

ACC is a precursor to the plant hormone ethylene, while the formation of ACC involves reactions with SAM. Hydrolysis of SAM by the transgenic enzyme SAMase, of which the gene is under the control of a ripening stagespecific promoter, inhibits ethylene formation and delays fruit ripening in GM tomatoes [128].

\section{Natural prevalence}

The E coli bacteriophage T7, which is closely related and highly similar to T3, does not contain the SAMase gene. In addition, the gene and amino acid sequences of the 0.3 protein from T7 phage, which also show antirestriction activity, do not show much similarity to those of T3 SAMase [129].

\section{Geographical distribution}

No specific data were available on the geographical distribution of the SAMase gene and its source, bacteriophage T3.

\section{Similarity to other microbial genes}

The native sequence of SAMase from bacteriophage T3 was used for FASTA analysis (accession X04791 [45], size $459 \mathrm{bp}$ ). This sequence shared a high degree of similarity with the 0.3 gene, which fulfils the same function in the bacteriophage phiYeO3-12 (Table 2). This "yersiniophage" infects Yersinia enterolytica serovar O:3 and its genome sequence shows a high overall similarity to that of T3 [133]. Interestingly, deletion of 0.3 gene from phiYe0312 did not impair the phage's efficiency in vitro [134].

No data were available on the sequence of the codonmodified SAMase transgene introduced into GM crops. Therefore, it was not possible to carry out a FASTA analysis with this sequence.

\section{Known horizontal gene transfer activity}

As previously mentioned, the native SAMase gene is located on a bacteriophage. The similarities and differences of the DNA, including the SAMase gene, between bacteriophages T3, T7 and phiYe03-12 has led to the hypothesis that $\mathrm{T} 3$ might have originated from a recombination event between T7 and yersiniophage. In a model experiment, recombination between T7 and phiYe03-12 was indeed observed in $E$ coli that had been genetically modified with the $\mathrm{O} 3$ receptor of $Y$ enterolytica in order to facilitate coinfection with both phages. The recombination of the SAMase-like gene 0.3 of phiYe03-12 was not observed in this case. The 0.3 gene was flanked upstream and downstream by stretches of identical nucleotides, which could be used for recombination, that is, horizontal transfer [135].

\section{Selective conditions and environments}

Mutant phages with T3 SAMase deleted are not less efficient, and SAMase therefore appears not to be essential for lytic activity (eg, [134]). We infer from this data that transfer of SAMase would not convey a selective advantage to recipient phages.

\section{Potential for pathogenicity or virulence}

As mentioned above, the cloning of SAMase into bacteria suppresses, among others, DNA methylation and biosynthesis of quorum sensing signaling molecules, both of which are known to stimulate virulence of microorganisms.

\section{Conclusion}

As mentioned above, the function of native SAMase is to prevent bacteriophages from degradation by infected bacterial hosts. In addition, expression of SAMase that has been cloned into bacteria may indirectly suppress pathogenicity of microorganisms by decreasing DNA methylation and the biosynthesis of quorum sensing signaling compounds. We conclude therefore that introduction of SAMase into mico-organisms by horizontal transfer is unlikely to contribute to pathogenicity. 


\section{$\beta$-glucuronidase (GUS) \\ Microbial source}

The uidA gene, which codes for the $\beta$-glucuronidase (GUS) enzyme, has been isolated from $E$ coli (reviewed in [136]). E coli is described in more detail in the section on the dam gene.

\section{Natural function}

GUS hydrolyzes glucuronide-conjugated compounds intracellularly in E coli, releasing the glucuronide [136].

The glucuronide released by GUS activity is used by $E$ coli as a carbon substrate for its metabolism [136].

\section{Function in GM crops}

The ability of GUS to convert chromogenic or fluorogenic substrates, yielding color or fluorescence development by the reaction, has also been exploited in biotechnology by using GUS from $E$ coli as a marker gene (reviewed in [137]). In addition, the use of transgenic maize plants expressing GUS for commercial production of this enzyme in purified form has also been reported [138].

\section{Natural prevalence}

E coli and other coliforms exhibit GUS activity. Besides coliform bacteria, a limited number of other microorganisms, including Shigella, also display such activity. Bacteroides and Clostridium are among the gut residents showing $\beta$-glucuronidase. Whereas their activity was weaker than for $E$ coli, these bacteria are generally more numerous in the gut [136]. GUS activity of E coli has been exploited for rapid tests to detect coliform bacteria in environmental, food, water, and clinical samples [139], indicating ubiquitous presence of GUS-activity.

The allele frequency within a $587 \mathrm{bp}$ fragment of the uida gene has been studied in environmental GUSpositive isolates of $E$ coli. In this study, 114 alleles were identified in 941 isolates, of which 60 alleles occurred in two or more isolates [140].

\section{Geographical distribution}

As mentioned above, GUS and $E$ coli are ubiquitously present in a range of environments.

\section{Similarity to other microbial genes}

For the FASTA analysis, the coding sequence of the native uidA gene coding for GUS from $E$ coli (accession S69414 [45], size 1812 bp) was used. Besides E coli, the 100 most similar sequences $(\mathrm{E} \leq 4.7 \mathrm{e}-153)$ in the results of the FASTA analysis within the prokaryote nucleotide database were from Shigella species. Within the database for fungal nucleotides, highly similar genes coding for GUS occurred in Penicillium canescens and Scopulariopsis (Table 2).

No data were available on the sequence of the codonmodified version of the uidA transgene present in GM crops. Due to this lack of data, no FASTA analysis could be carried out on the codon-modified uidA transgene.

\section{Known horizontal gene transfer activity}

The uida gene is located on the chromosome of E coli, and is part of the GUS-operon [136]. The presence of highly similar sequences coding for GUS in soil isolates of $P$ canescens and Scopulariopsis fungi and Arthrobacter bacteria has recently been described. In this study, the hypothesis was tested that gus genes would be amenable to horizontal gene transfer from bacteria to fungi. This hypothesis was based on the assumption that gus would convey to fungi in soil the capacity to utilise glucuronides excreted by animals as a source of carbon. Based on characteristics of the gus genes and their products in these fungi and Arthrobacter, the authors concluded that these genes must have been derived from a common ancestor [141].

\section{Selective conditions and environments}

As mentioned previously, the horizontally transferred uida gene is assumed by other authors to convey a selective advantage to recipient soil microorganisms, since GUS enables the utilisation of glucuronides derived from animal excretions shed onto land [141].

\section{Potential for pathogenicity or virulence}

GUS activity is generally considered to be absent from a minority of all $E$ coli strains, including the pathogenic, enterohaemorrhagic E coli O157:H7. The gus gene is still present in this and other $E$ coli strains lacking GUS activity, the inactivity probably being caused by mutations in this gene [142, 143, 144]. Recent reports, however, describe incidences of $E$ coli O157:H7 showing GUS activity (eg, [145]).

GUS activity contributes to the so-called enterohepatic circulation of hydrophobic compounds in humans and animals. During this process, compounds are glucuronidated in the liver, excreted through the bile into the gut, deglucuronidated by the gut flora, and subsequently absorbed from the gut [136].

In addition, bacterial beta-glucuronidase activity has been considered to be one of the factors that contribute to the formation of gallstones in the liver. This is thought to be due to the deglucuronidation of bilirubin glucuronides present in the gall, which would facilitate the formation of calcium bilirubinate, a component of gallstones [146].

\section{Conclusion}

As described above, there is a ubiquitous background presence of GUS in a range of environments, including the intestinal microflora. In addition, no link is evident between GUS and the pathogenicity of particular $E$ coli strains. We conclude therefore that it is unlikely that 
the horizontal transfer of GUS, if it would occur, would have a noticeable impact on intestinal GUS activity or on pathogenicity of recipient organisms.

\section{Nopaline synthase (NOS)}

Microbial source

The native tumor-inducing plasmid pTiC58 of Agrobacterium tumefaciens strain C58 harbours among others the gene nos encoding nopaline synthase. This plasmid is transferred to plants infected by A tumefaciens causing the formation of calli, that is, "crown gall tumors" [147].

\section{Natural function}

Nopaline synthase (NOS), which is also known as nopaline dehydrogenase, catalyzes the formation of nopaline $\left[N^{2}-(1,3\right.$-dicarboxypropyl)arginine] from the precursors $\alpha$-ketoglutaric acid and arginine in an NADPHdependent reaction. It also catalyzes the formation of ornaline $\left[N^{2}-(1,3\right.$-dicarboxypropyl)ornithine $]$ from $\alpha$ ketoglutaric acid and ornithine [147].

The transfer of the nos gene to infected plant cells triggers the synthesis by these cells of nopaline, which is one of the "opines" that can be utilised as substrate by A tumefaciens [148]. For example, both "octopine" and "nopaline" types of crown galls can be discerned, while the latter has been associated with nopaline synthase activity [147].

\section{Function in GM crops}

Nopaline synthase has been engineered into transgenic flax in order to serve as a transformation marker that facilitated detection of transformed plant embryos by the presence of nopaline (see the Canadian regulatory evaluation document [149]).

\section{Natural prevalence}

The amino acid sequences of NOS and octopine synthase share domains of comparatively high sequence similarity with each other and, to a lesser degree, with dehydrogenase enzymes from other organisms [150]. Besides Agrobacterium, related opine dehydrogenase enzymes also occur in the bacterium Arthrobacter and aquatic invertebrates $[151,152]$. In the latter, these enzymes have a role in the anaerobic glycolysis, that is, in energy metabolism [152].

\section{Geographical distribution}

No data were available on the geographical distribution of the nos gene. The microbial host of the pTiC58 plasmid, A tumefaciens C58, is able to grow in association with plants around the globe [153]. More generally, Agrobacterium species occur widely in soils from different geographical origins, as described above for the cp4 epsps gene.

\section{Similarity to other microbial genes}

The coding sequence of the native nos gene from Agrobacterium tumefaciens plasmid pTiC58 was used for the FASTA analysis (accession AJ237588 [45], size $1242 \mathrm{bp}$ ). The results of this analysis showed that the nos gene shared a high degree of similarity with the corresponding gene on plasmid pTiAB4 of the related Agrobacterium vitis (Table 2). The actual sequence of the nos transgene introduced into GM crops was not available and therefore no analysis could be carried out on this sequence.

\section{Known horizontal gene transfer activity}

The microbial native nos transgene is located on plasmid pTiC58, as previously mentioned. In a model experiment with nonsterile soil, the conjugative transfer of a modified pTiC58 plasmid from Agrobacterium to other bacteria was observed [154]. While this study did not specifically analyze for the transfer of the nos gene, it showed that the native plasmid carrying nos could be transferred horizontally by conjugation.

The $A$ vitis plasmid pTiAB4 shows similarity to other plant "tumor-inducing" (Ti) plasmids, such as, for example, a fragment containing the nos gene that was very similar to the pTiC58 (source of the transgene). These similarities were considered by Otten and De Ruffray [155] to originate from horizontal transfer between Ti plasmids.

\section{Selective conditions and environments}

No data were available that in our opinion would indicate a particular selective advantage for the nos gene to recipients after its potential horizontal transfer.

\section{Potential for pathogenicity or virulence}

The nos gene has a role in the pathogenicity of its native host $A$ tumefaciens in plants, as described above, while neither one is known to have a role in pathogenicity or virulence of human or animal pathogens.

\section{Conclusion}

As mentioned above, the nos gene has a specific role in plant pathogenesis by A tumefaciens. We therefore conclude that its potential horizontal transfer to microorganisms would unlikely contribute to the latter's human and animal pathogenicity.

\section{Cry proteins}

\section{Microbial source}

The source of the cry genes used for genetic modification of crops is Bacillus thuringiensis. This bacterium was described for the first time in 1901 following its isolation from diseased silkworm larvae. It was observed later that these bacteria produced spores containing crystals that are 
toxic to insects. These crystals contain, among others, the Cry proteins encoded by cry genes located on plasmids and on the chromosome. The insecticidal properties of $B$ thuringiensis and its crystal inclusions have been exploited for the production as biological pesticides since 1938 (reviewed in [156]).

The classification of subspecies of $B$ thuringiensis is based upon serological reactions of the H-flagellae [157]. The various cry genes that have been introduced in the GM crops and their sources are mentioned in Table 4. In addition, a website dedicated to the nomenclature of Cry proteins provides the database accession and host strain for each protein [158].

$B$ thuringiensis, including the subspecies from which the cry transgenes are derived, occurs ubiquitously in the environment, including soil, water, sediment, plant leaves, and food (eg, [167, 168, 169, 170]).

These Cry proteins are subdivided into various groups based on the degree of similarity between their amino acid sequences [171].

\section{Natural function}

The active subsequence of Cry proteins, which is released by enzymes in the insect gut, is composed of three domains. Two of these domains participate in the binding of the Cry protein to aminopeptidase $\mathrm{N}$ receptor molecules on the surface of epithelial cells lining the insect gut. The third domain subsequently forms pores in the cell membrane, leading to leaching and, finally, insect lethality. Distinct classes of Cry proteins show activities against specific insects, such as CrylAb against Lepidoptera and Cry3Aa against Coleoptera (reviewed in [172]).

The insecticidal mechanism is very specific as the Cry proteins are not bound by intestinal tissues of humans and experimental rodents, for which these proteins are nontoxic (eg, [173]).

\section{Function in GM crops}

A number of insecticidal Cry proteins originating from various strains of Bacillus thuringiensis have been engineered into GM crops in order to protect these crops from phytophagous (plant-feeding) insects (reviewed in [174]).

\section{Natural prevalence}

Whereas the ubiquitous presence of $B$ thuringiensis strains has been acknowledged for a long time, studies screening for the occurrence of cry genes are of a comparatively recent date. These studies were reviewed by Porcar and Juarez-Perez [175]. The frequency of detection may differ from one particular type of cry gene to another. For example, within the group of $c r y 1$ genes, which are frequently observed, $c r y 1 F$ appears to be less common than, for example, $c r y 1 A[175,176]$. In addition, combinations of cry genes can be detected in single isolates of $B$ thuringiensis, which may be specific for certain strains, geographical origins, or ecological systems (eg, [177, 178]).

Cry sequences have also been identified in various bacteria other than Bacillus thuringiensis. For example, the $c r y 16 A a$ and $c r y 17 A a$ genes have been identified in a strain of Clostridium bifermentans with insecticidal activity against dipterans [179].

In addition, cry genes have been identified in Paenibacillus, including cry $43 \mathrm{Aa}$, cry $43 \mathrm{Ba}$, and cry 43 -like from $P$ lentimorbus [180], as well as cry18Aa from $P$ popilliae [181]. Given that $P$ popilliae acts differently from $B$ thuringiensis, that is, as a parasite of beetles (coleopterans) rather than an insecticide, Zhang et al [181] argued that the Cry18Aa protein should have a different role in insect pathology than that of the Cry proteins from $B$ thuringiensis.

The amino acid sequence of the $c r y 35 a b$ gene product from $B$ thuringiensis PS149B1 shows similarity to the 41.9-kilodalton protein from Bacillus sphaericus. Interestingly, both proteins are only toxic to target insects in combination with a coexpressed protein, that is, Cry $34 \mathrm{Ab}$ and Cry35Ab in corn rootworm and the 41.9- and 51.4kilodalton proteins in mosquitoes $[182,183]$.

\section{Geographical distribution}

Similar to the occurrence of $c r y$ genes described above, studies on the geographical distribution of these genes have been carried out recently. These studies were reviewed by Porcar and Juarez-Perez [175], while additional data have been published since then $[176,184,185,186]$. The results of these studies indicate that in general many cry genes are present in isolates of $B$ thuringiensis from a wide range of geographical origins, including Latin America, Asia, and Europe.

\section{Similarity to other microbial genes}

FASTA analysis of the native versions of the cry genes that have been introduced into GM crops showed no similarities of $\mathrm{E}<1^{*} 10^{-30}$ or minimally $2 \times 20 \mathrm{bp}$ other than with other accessions for sequences from Bacillus thuringiensis (Table 2). In some cases, that is, for cry $1 \mathrm{Ab}$ and $c r y 1 A c$, the highest E-value of the 100 best scoring alignments (maximum output) with the prokaryote nucleotide sequence database was still below the threshold of $\mathrm{E}<1^{*} 10^{-30}$. The codon-modified versions of the $c r y$ transgenes introduced into GM crops have not been analysed by FASTA, because their sequences were not available.

\section{Known horizontal gene transfer activity}

With regard to the presence of cry genes in Clostridium (see above), Barloy et al [179] suggested that mobile elements, such as transposons, might have contributed to the dissemination of these genes.

The native microbial cry transgenes occur both on plasmids and in the chromosome of Bacillus thuringiensis 
(eg, [187]). Transfer of these genes by exchange of transmissible plasmids through conjugation with other strains of $B$ thuringiensis and Bacillus species has been observed under laboratory conditions $[188,189]$.

Based on his review of structural similarities of the various Cry proteins, de Maagd et al [172] postulated that "domain swapping" might have occurred between $c r y$ genes through homologous recombination. Such an exchange of domains can be accomplished under laboratory conditions and can change the activity spectrum of the resultant mutant Cry protein [172].

\section{Selective conditions and environments}

Cry proteins may constitute an important virulence factor of strains of $B$ thuringiensis and $B$ cereus that are opportunistic insect pathogens [190]. We therefore speculate that horizontally transferred cry genes would, in theory, convey a selective advantage to recipient microorganisms lacking these genes within the insect environment.

\section{Potential for pathogenicity or virulence}

$B$ thuringiensis is genetically related to Bacillus anthracis and $B$ cereus, which are known pathogens, $B$ anthracis causing anthrax and $B$ cereus causing opportunistic infections. The specific phenotypic characteristics of $B$ thuringiensis and $B$ anthracis are associated with extrachromosomal elements [191]. Based upon extensive review of the safety data on $B$ thuringiensis to animals and humans, various sources have concluded that $B$ thuringiensis preparations are safe (eg, $[157,192])$.

\section{Conclusion}

As described above, native cry genes display ubiquitous presence and have also been detected in foods. Overall reviews of safety data indicate that there is no toxicity of Cry proteins to humans [157, 174, 192]. We therefore conclude that the horizontal gene transfer of cry genes from plants to microorganisms, if it would occur, is unlikely to contribute to pathogenicity of recipient microorganisms in humans and domestic animals.

\section{DISCUSSION}

The microbial genes that have been introduced into market-approved GM crops constitute a fairly heterogenous group with regard to source and function in microorganisms. In the safety assessment of these crops so far, the focus has been on antibiotic resistance genes. In this work, the function and characteristics of microbial transgenes other than antibiotic resistance genes as well as the potential health aspects of their horizontal transfer have been discussed. In the survey, we took into account characteristics of the transgenes that might be relevant to health. These characteristics included the microbial source of the native transgene; the function of the transgene in its natural environment and in genetically modified crops; the natural prevalence and geographical distribution of the native and similar transgenes; the homology to genes of other microbial species, which is also indicative for the background presence and the likelihood of transfer, that is, by homologous recombination; known horizontal transfer activity of the transgene; and the potential contribution of the transgene to pathogenicity or virulence of human and animal microbial pathogens. Each single item may not be totally predictive of gene transfer and associated health effects and therefore the "weighed evidence" of the items in combination should be considered. In many cases, it was noted that there was a wideranging background presence, a specific function, or an apparent lack of relationship with pathogenicity of the gene considered. We concluded for each gene that its potential horizontal transfer to microorganisms would unlikely raise health concerns.

In addition, we noted some conspicuous items for the genes considered. For example, the presence in soil fungi of analogues of the bacterial gene coding for $\beta$ glucuronidase might originate from a horizontal transfer between bacteria and fungi, as reported recently in literature [141]. Interestingly, this gene was considered by the author of the study to convey a selective advantage to the recipient fungi, since it would allow for utilisation of glucuronides from excretions (feces, urine) of animals. In a more general sense, we may extend this to survival and competitive advantage of microorganisms in the environment, including the soil. In this respect, also the transfer of herbicide resistance genes may, in theory, provide a selective advantage to soil microorganisms sensitive to herbicide action, as may the transfer of the ACC deaminase gene to microorganisms colonising the rhizosphere of plants. It may be speculated that an increased survivability of pathogens in the environment may indirectly increase the likelihood of exposure to these pathogens.

Another conspicuous item was the presence in live attenuated oral vaccines of mutated aroa genes, which are functional analogs of the cp4 epsps transgene in herbicideresistant crops. We consider the likelihood of repair of the mutant genes by homologous recombination with the transgene to be comparatively low or absent, given the lack of similarity to aroa genes in precommercial vaccines and the background presence of aroa genes in other microorganisms. Some experimental GM crops have been modified with bacterial aroa genes other than cp4 epsps, such as aroa from $S$ typhimurium, of which mutants have also been used as attenuated live vaccines. A discussion on experimental GM crops is, however, beyond the scope of this paper.

Some of these experimental GM crops may enter the market in the near future and contain novel traits and transgenes, which should also be assessed for their safety by a comparative safety assessment [3]. The section on gene transfer of the FAO/WHO Codex Alimentarius guidelines for the safety assessment of foods derived 
from GM crops focuses on antibiotic resistance [2]. The potential impact of gene transfer on the pathogenicity of recipient microorganisms is also an important item in practice, however. We therefore recommend considering the abovementioned items, including the characteristics of transgenes and their native counterparts, in the safety assessment of GMOs carrying transgenes other than those reviewed in this paper.

\section{ACKNOWLEDGMENTS}

The authors gratefully acknowledge financial support from the Dutch Ministry of Agriculture, Nature, and Food Quality. In addition, the authors wish to thank Ms. Ir. E. J. Kok for her comments on the manuscript.

\section{REFERENCES}

[1] James C. Global Status of Commercialized Biotech/ GM Crops: 2004. Ithaca: International Service for the Acquisition of Agri-Biotech Applications; 2004. ISAAA Briefs No. 32-2004. http://www.isaaa.org/ kc/CBTNews/press_release/briefs32/ESummary/ Executive\%20Summary\%20 (English).pdf.

[2] Codex Alimentarius Commission. Codex Principles and Guidelines on Foods Derived from Biotechnology. Rome, Italy:Food and Agriculture Organisation; 2003. Codex Alimentarius Commission, Joint FAO/WHO Food Standards Programme. ftp://ftp.fao.org/codex/standard/en/CodexTexts BiotechFoods.pdf.

[3] Kok EJ, Kuiper HA. Comparative safety assessment for biotech crops. Trends Biotechnol. 2003;21(10): 439-444.

[4] Kuiper HA, Kleter GA, Noteborn HP, Kok EJ. Assessment of the food safety issues related to genetically modified foods. Plant J. 2001;27(6):503-528.

[5] van den Eede G, Aarts H, Buhk HJ, et al. The relevance of gene transfer to the safety of food and feed derived from genetically modified (GM) plants. Food Chem Toxicol. 2004;42(7):1127-1156.

[6] Lorenz MG, Wackernagel W. Bacterial gene transfer by natural genetic transformation in the environment. Microbiol Rev. 1994;58(3):563-602.

[7] Smalla K, Gebhard F, Van Elsas JD, Matzk A, Schiemann J. Bacterial communities influenced by transgenic plants. In: Jones DD, ed. Proceedings of the 3rd Symposium on the Biosafety Results of Field Tests of Genetically Modified Plants and Microorganisms. Monterey; Oakland:University of California; 1994:157-167.

[8] Schlüter K, Fütterer J, Potrykus I. "Horizontal" gene transfer from a transgenic potato line to a bacterial pathogen (Erwinia chrysanthemi) occurs-if at all-at an extremely low frequency. Biotechnology (NY). 1995;13(10):1094-1098.

[9] Dröge M, Pühler A, Selbitschka W. Horizontal gene transfer as a biosafety issue: a natural phenomenon of public concern. J Biotechnol. 1998;64(1):75-90.
[10] Nielsen KM, Gebhard F, Smalla K, Bones AM, Van Elsas JD. Evaluation of possible horizontal gene transfer from transgenic plants to the soil bacterium Acinetobacter calcoaceticus BD413. Theoretical and applied genetics. 1997;95:815-821.

[11] Tepfer D, Garcia-Gonzales R, Mansouri H, et al. Homology-dependent DNA transfer from plants to a soil bacterium under laboratory conditions: implications in evolution and horizontal gene transfer. Transgenic Res. 2003;12(4):425-437.

[12] Ceremonie H, Buret F, Simonet P, Vogel TM. Isolation of lightning-competent soil bacteria. Appl Environ Microbiol. 2004;70(10):6342-6346.

[13] Edwards RA, Olsen GJ, Maloy SR. Comparative genomics of closely related salmonellae. Trends Microbiol. 2002;10(2):94-99.

[14] Jacob D, Lewin A, Meister B, Appel B. Plant-specific promoter sequences carry elements that are recognised by the eubacterial transcription machinery. Transgenic Res. 2002;11(3):291-303.

[15] Lewin A, Tran TT, Jacob D, Mayer M, Freytag B, Appel B. Yeast DNA sequences initiating gene expression in Escherichia coli. Microbiol Res. 2004;159(1):19-28.

[16] Jonas DA, Elmadfa I, Engel KH, et al. Safety considerations of DNA in food. Ann Nutr Metab. 2001;45(6):235-254.

[17] Straub JA, Hertel C, Hammes WP. The fate of recombinant DNA in thermally treated fermented sausages. Eur Food Res Technol. 1999;210:62-67.

[18] van der Vossen JMBM, Havekes WALM, Koster DS, et al. Development and application of in vitro intestinal tract model for safety evaluation of genetically modified foods. In: Food Safety Evaluation of Genetically Modified Foods as a Basis for Market Introduction: Market Introduction Genetically Modified Foods. The Hague, The Netherlands:Ministry of Economic Affairs; 1998:81-98.

[19] Wilcks A, van Hoek AH, Joosten RG, Jacobsen BB, Aarts HJ. Persistence of DNA studied in different $e x$ vivo and in vivo rat models simulating the human gut situation. Food Chem Toxicol. 2004;42(3):493502.

[20] Netherwood T, Martín-Orúe SM, O’Donnell AG, et al. Assessing the survival of transgenic plant DNA in the human gastrointestinal tract. Nat Biotechnol. 2004;22(2):204-209.

[21] Bauer F, Hertel C, Hammes WP. Transformation of Escherichia coli in foodstuffs. Syst Appl Microbiol. 1999;22(2):161-168.

[22] Kharazmi M, Sczesny S, Blaut M, Hammes WP, Hertel C. Marker rescue studies of the transfer of recombinant DNA to Streptococcus gordonii in vitro, in foods and gnotobiotic rats. Appl Environ Microbiol. 2003;69(10):6121-6127.

[23] Kharazmi M, Bauer T, Hammes WP, Hertel C. Effect of food processing on the fate of DNA with regard to degradation and transformation 
capability in Bacillus subtilis. Syst Appl Microbiol. 2003;26(4):495-501.

[24] Hacker J, Kaper JB. Pathogenicity islands and the evolution of microbes. Annu Rev Microbiol. 2000;54:641-679.

[25] Wain J, House D, Pickard D, Dougan G, Frankel G. Acquisition of virulence-associated factors by the enteric pathogens Escherichia coli and Salmonella enterica. Philos Trans Roy Soc London Ser B Biol Sci. 2001;356:1027-1034.

[26] Cao H, Baldini RL, Rahme LG. Common mechanisms for pathogens of plants and animals. Annu Rev Phytopathol. 2001;39:259-284.

[27] van Burik JA, Magee PT. Aspects of fungal pathogenesis in humans. Annu Rev Microbiol. 2001;55:743-772.

[28] European Commission. 94/211/EC: Commission Decision of 15 April 1994 amending Council Decision 91/596/EEC concerning the summary notification information format referred to in Article 9 of Council Directive 90/220/EEC. Off J Eur Commun. 1994;105:26-44.

[29] FDA. List of Completed Consultations on Bioengineered Foods. Washington DC:Office of Food Additive Safety, Center for Food Safety and Applied Nutrition, US Food and Drug Administration; 2005. http://www.cfsan.fda.gov/ lrd/biocon.html.

[30] CFIA. Status of Regulated Plants with Novel Traits in Canada: Unconfined Environmental Release, Novel Livestock Feed Use, Variety Registration and Novel Food Use. Nepean:Plant Biosafety Office, Plant Products Directorate, Canadian Food Inspection Agency; 2005. http://www.inspection.gc.ca/ english/plaveg/bio/pntvcne.shtml.

[31] European Commission. Lists of Authorised GMOs. Brussels:Directorate General Health and Consumer Affairs, European Commission; 2005. http://europa.eu.int/comm/food/food/biotechnology/ gmfood/index_en.htm.

[32] FSANZ. GM Foods-Current Applications and Approvals (Updated February 2005). Canberra and Wellington:Food Standards Australia New Zealand; 2005. http://www.foodstandards.gov.au/ whatsinfood/gmfoods/gmcurrentapplication 1030. cfm.

[33] Watt VM, Ingles CJ, Urdea MS, Rutter WJ. Homology requirements for recombination in Escherichia coli. Proc Natl Acad Sci USA, 1985;82:4768-4772.

[34] WHO. Health Aspects of Marker Genes in Genetically Modified Plants. Geneva, Switzerland:World Health Organisation; 1993. Report of a WHO Workshop WHO/FNU/FOS/93.6.

[35] Biet E, Sun JS, Dutreix M. Stimulation of Dloop formation by polypurine/polypyrimidine sequences. Nucleic Acids Res. 2003;31(3):1006-1012.

[36] Pearson WR, Wood TC. Statistical significance in biological sequence comparison. In: Balding DJ,
Bishop M, Cannings C, eds. Handbook of Statistical Genetics. London,UK:Wiley; 2001:39-65.

[37] Nielsen KM. An assessment of factors affecting the likelihood of horizontal transfer of recombinant plant DNA to bacterial recipients in the soil and phytosphere. In: Collection of Biosafety Reviews. 1st ed. Italy:ICGEB, Italian Ministry of Environment; 2003:96-149.

[38] McBride KE, Kenny JW, Stalker DM. Metabolism of the herbicide bromoxynil by Klebsiella pneumoniae subsp. ozaenae. Appl Environ Microbiol. 1986;52(2):325-330.

[39] Stalker DM, McBride KE, Malyj LD. Herbicide resistance in transgenic plants expressing a bacterial detoxification gene. Science. 1988;242:419-423.

[40] Stalker DM, Malyj LD, McBride KE. Purification and properties of a nitrilase specific for the herbicide bromoxynil and corresponding nucleotide sequence analysis of the bxn gene. J Biol Chem. 1988;263(13):6310-6314.

[41] Kato Y, Ooi R, Asano Y. Distribution of aldoxime dehydratase in microorganisms. Appl Environ Microbiol. 2000;66(6):2290-2296.

[42] Banerjee A, Sharma R, Banerjee UC. The nitriledegrading enzymes: current status and future prospects. Appl Microbiol Biotechnol. 2002;60(12):33-44.

[43] O'Reilly C, Turner PD. The nitrilase family of CN hydrolysing enzymes - a comparative study. J Appl Microbiol. 2003;95(6):1161-1174.

[44] Brandão PF, Clapp JP, Bull AT. Discrimination and taxonomy of geographically diverse strains of nitrile-metabolizing actinomycetes using chemometric and molecular sequencing techniques. Environ Microbiol. 2002;4(5):262-276.

[45] NCBI Nucleotide Databank. http://www.ncbi.nlm. nih.gov/entrez/query.fcgi?db=Nucleotide.

[46] Stalker DM, McBride KE. Cloning and expression in Escherichia coli of a Klebsiella ozaenae plasmidborne gene encoding a nitrilase specific for the herbicide bromoxynil. J Bacteriol. 1987;169(3):955960.

[47] Goldstein EJC, Lewis RP, Martin WJ, Edelstein PH. Infections caused by Klebsiella ozaenae: a changing disease spectrum. J Clin Microbiol. 1978;8:413-418.

[48] Padgette SR, Re DB, Barry GF, et al. New weed control opportunities: development of soybeans with a Roundup Ready ${ }^{\mathrm{TM}}$ gene. In: Duke SO, ed. Herbicide-Resistant Crops: Agricultural, Environmental, Economic, Regulatory, and Technical Aspects. Boca Raton, Fla: CRC Lewis; 1996:53-84.

[49] Farrand SK, Van Berkum PB, Oger P. Agrobacterium is a definable genus of the family Rhizobiaceae. Int J Syst Evol Microbiol. 2003;53(pt 5):16811687.

[50] Bala A, Murphy P, Giller KE. Distribution and diversity of rhizobia nodulating agroforestry legumes 
in soils from three continents in the tropics. $\mathrm{Mol}$ Ecol. 2003;12(4):917-929.

[51] Paulsen IT, Seshadri R, Nelson KE, et al. The Brucella suis genome reveals fundamental similarities between animal and plant pathogens and symbionts. Proc Natl Acad Sci USA. 2002;99(20):1314813153.

[52] Tsolis RM. Comparative genome analysis of the alpha-proteobacteria: relationships between plant and animal pathogens and host specificity. Proc Natl Acad Sci USA. 2002;99(20):12503-12505.

[53] Alsmark CM, Frank AC, Karlberg EO, et al. The louse-borne human pathogen Bartonella quintana is a genomic derivative of the zoonotic agent Bartonella henselae. Proc Natl Acad Sci USA. 2004; 101(26):9716-9721.

[54] Son DY. Sequencing, cloning and expression of CP4EPSPS roundup ready soybean insert. Food Sci Biotechnol. 2003;12:133-136.

[55] Barry GF, Kishore GM. Glyphosate-tolerant 5enolpyruvylshikimate-3-phosphate synthases. US patent 5804 425. 1998;151 pp.

[56] Schödel F, Curtiss R. Salmonellae as oral vaccine carriers. Dev Biol Stand. 1995;84:245-253.

[57] Stocker BAD. Aromatic-dependent salmonella as anti-bacterial vaccines and as presenters of heterologous antigens or of DNA encoding them. $J$ Biotechnol. 2000;83(1-2):45-50.

[58] Marsden MJ, Vaughan LM, Fitzpatrick RM, Foster TJ, Secombes CJ. Potency testing of a live, genetically attenuated vaccine for salmonids. Vaccine. 1998;16(11-12):1087-1094.

[59] Cooke McGraw L. First genetically engineered vaccine for shipping fever. Agricultural Research Magazine. 1998;46(12):20.

[60] Australian Poultry CRC. Towards Rapid Registration of a Live Attenuated Pasteurella multocida Vaccine. Armidale, Australia:Australian Poultry Cooperative Research Center. 2004. Tech. Rep. 03.012. http://www1.poultrycrc.com.au/pages/project. aspx?projectid $=87$.

[61] Aquaflow. Development of a Multi-specific Vaccine. Oostende, Belgium:European Network for the Dissemination of Aquaculture RTD Information, European Aquaculture Society; 1998. Technical Leaflet TL1998-025. http://www.aquaflow.org/ home/default.asp.

[62] Foulongne V, Walravens K, Bourg G, et al. Aromatic compound-dependent Brucella suis is attenuated in both cultured cells and mouse models. Infect Immun. 2001;69(1):547-550.

[63] Hong PC, Tsolis RM, Ficht TA. Identification of genes required for chronic persistence of Brucella abortus in mice. Infect Immun. 2000;68(7):41024107.

[64] Barry GF, Kishore GM. Glyphosate tolerant plants. US patent $5776760.1998 ; 73$ pp.
[65] Carson DB, Heitkamp MA, Hallas LE. Biodegradation of N-phosphonomethyliminodiacetic acid by microorganisms from industrial activated sludge. Can J Microbiol. 1997;43(1):97-101.

[66] Jacob GS, Garbow JR, Hallas LE, Kimack NM, Kishore GM, Schaefer J. Metabolism of glyphosate in Pseudomonas sp. strain LBr. Appl Environ Microbiol. 1988;54(12):2953-2958.

[67] Forlani G, Mangiagalli A, Nielsen E, Suardi CM. Degradation of the phosphonate herbicide glyphosate in soil: evidence for a possible involvement of unculturable microorganisms. Soil Biol Biochem. 1999;31(7):991-997.

[68] Dick RE, Quinn JP. Glyphosate-degrading isolates from environmental samples: occurrence and pathways of degradation. Appl Microbiol Biotechnol. 1995;43(3):545-550.

[69] Obojska A, Ternan NG, Lejczak B, Kafarski P, McMullan G. Organophosphonate utilization by the thermophile Geobacillus caldoxylosilyticus T20. Appl Environ Microbiol. 2002;68(4):2081-2084.

[70] Bertrand H, Plassard C, Pinochet X, Touraine B, Normand P, Cleyet-Marel JC. Stimulation of the ionic transport system in Brassica napus by a plant growth-promoting rhizobacterium (Achromobacter sp.). Can J Microbiol. 2000;46(3):229-236.

[71] Mayak S, Tirosh T, Glick BR. Plant growthpromoting bacteria confer resistance in tomato plants to salt stress. Plant Physiol Biochem. 2004;42(6):565-572.

[72] Rojas Avelizapa NG, Rodriguez Vasquez R, Enriquez Villanueva F, Martinez Cruz J, Poggi Varaldo HM. Transformer oil degradation by an indigenous microflora isolated from a contaminated soil. Resources Conservat Recycl. 1999;27:15-26.

[73] Kjær J, Olsen P, Ullum M, Grant R. Leaching of glyphosate and amino-methylphosphonic acid from Danish agricultural field sites. J Environ Qual. 2005;34(2):608-620.

[74] Major WW, Grue CE, Gardner SC, Grassley JM. Concentrations of Glyphosate and AMPA in sediment following operational applications of Rodeo@ to control smooth cordgrass in Willapa Bay, Washington, USA. Bull Environ Contam Toxicol. 2003;71:912-918.

[75] Araujo AS, Monteiro RT, Abarkeli RB. Effect of glyphosate on the microbial activity of two Brazilian soils. Chemosphere. 2003;52(5):799-804.

[76] Aisenberg G, Rolston KV, Safdar A. Bacteremia caused by Achromobacter and Alcaligenes species in 46 patients with cancer (1989-2003). Cancer. 2004;101(9):2134-2140.

[77] Gomez-Cerezo J, Suarez I, Rios JJ, et al. Achromobacter xylosoxidans bacteremia: a 10-year analysis of 54 cases. Eur J Clin Microbiol Infect Dis. 2003;22(6):360-363. 
[78] Lea PJ, Joy KW, Ramos JL, Guerrero MG. The action of 2-amino-4-(methylphosphinyl)-butanoic acid (phosphinothricin) and its 2-oxo-derivative on the metabolism of cyanobacteria and higher plants. Phytochemistry. 1984;23:1-6.

[79] Omura S, Murata M, Hanaki H, Hinotozawa K, Oiwa R, Tanaka H. Phosalacine, a new herbicidal antibiotic containing phosphinothricin. Fermentation, isolation, biological activity and mechanism of action. J Antibiot (Tokyo). 1984;37(8):829-835.

[80] Wehrmann A, Van Vliet A, Opsomer C, Botterman J, Schulz A. Thesimilarities of bar and pat gene products make them equally applicable for plant engineers. Nat Biotechnol. 1996;14(10):1274-1278.

[81] Thompson CJ, Movva NR, Tizard R, et al. Characterization of the herbicide-resistance gene bar from Streptomyces hygroscopicus. EMBO J. 1987;6:2519-2523.

[82] Vinnemeier J, Droege-Laser W, Pistorius EK, Broer I. Purification and partial characterization of the Streptomyces viridochromogenes Tü494 phosphinothricin-N-acetyltransferase mediating resistance to the herbicide phosphinothricin in transgenic plants. Z Naturforsch. 1995;50C:796805.

[83] Kumada Y, Anzai H, Takano E, et al. The bialaphos resistance gene (bar) plays a role in both selfdefense and bialaphos biosynthesis in Streptomyces hygroscopicus. J Antibiot (Tokyo). 1988;41(12): 1838-1845.

[84] Bedford DJ, Lewis CG, Buttner MJ. Characterization of a gene conferring bialaphos resistance in Streptomyces coelicolor A3(2). Gene. 1991;104(1):39-45.

[85] Anzai H, Murakami T, Imai S, Satoh A, Nagaoka $\mathrm{K}$, Thompson CJ. Transcriptional regulation of bialaphos biosynthesis in Streptomyces hygroscopicus. J Bacteriol. 1987;169(8):3482-3488.

[86] Strauch E, Wohlleben W, Puhler A. Cloning of a phosphinothricin $\mathrm{N}$-acetyltransferase gene from Streptomyces viridochromogenes Tu494 and its expression in Streptomyces lividans and Escherichia coli. Gene. 1988;63(1):65-74.

[87] Welker NE, Campbell LL. Unrelatedness of Bacillus amyloliquefaciens and Bacillus subtilis. J Bacteriol. 1967;94(4):1124-1130.

[88] Hill C, Dodson G, Heinemann U, et al. The structural and sequence homology of a family of microbial ribonucleases. Trends Biochem Sci. 1983;8:364369.

[89] Hartley RW. Barnase and barstar: two small proteins to fold and fit together. Trends Biochem Sci. 1989;14(11):450-454.

[90] Mariani C, Gossele V, De Beuckeleer M, et al. A chimaeric ribonuclease-inhibitor gene restores fertility to male sterile plants. Nature. 1992;357:384-387.

[91] Aravind L, Koonin EV. A natural classification of ribonucleases. Methods Enzymol. 2001;341:3-28.
[92] Krajcikova D, Hartley RW, Sevcik J. Isolation and purification of two novel streptomycete RNase inhibitors, SaI14 and SaI20, and cloning, sequencing, and expression in Escherichia coli of the gene coding for SaI14. J Bacteriol. 1998;180(6):1582-1585.

[93] Krajcikova D, Hartley RW. A new member of the bacterial ribonuclease inhibitor family from Saccharopolyspora erythraea. FEBS Lett. 2004;557(13):164-168.

[94] Hartley RW. Barnase and barstar. Expression of its cloned inhibitor permits expression of a cloned ribonuclease. J Mol Biol. 1988;202(4):913-915.

[95] Paddon CJ, Hartley RW. Cloning, sequencing and transcription of an inactivated copy of Bacillus amyloliquefaciens extracellular ribonuclease (barnase). Gene. 1985;40(2-3)231-239.

[96] Burgess DG, Ralston EJ, Hanson WG, et al. A novel, two-component system for cell lethality and its use in engineering nuclear male-sterility in plants. Plant J. 2002;31(1):113-125.

[97] Hartley RW. Homology between prokaryotic and eukaryotic ribonucleases. J Mol Evol. 1980;15(4):355-358.

[98] Pedersen PB, Bjørnvad ME, Rasmussen MD, Petersen JN. Cytotoxic potential of industrial strains of Bacillus sp. Regul Toxicol Pharmacol. 2002;36(2): 155-161.

[99] EFSA. Opinion of the FEEDAP Panel on the Safety of the Product "Kemzyme W Dry" Regarding the Ability of Bacillus Strains Involved in the Manufacture to Produce Toxins. Brussels/Parma:European Food Safety Authority; 2004. Question No EFSA-Q2004-111, Adopted on 19 November 2004. http:// www.efsa.eu.int/science/feedap/feedap_opinions/ 701_en.html.

[100] Lazdunski CJ, Bouveret E, Rigal A, Journet L, Lloubes R, Benedetti H. Colicin import into Escherichia coli cells. J Bacteriol. 1998;180(19):49935002.

[101] Makarov AA, Ilinskaya ON. Cytotoxic ribonucleases: molecular weapons and their targets. FEBS Lett. 2003;540(1-3):15-20.

[102] Paris S, Monod M, Diaquin M, et al. A transformant of Aspergillus fumigatus deficient in the antigenic cytotoxin ASPFI. FEMS Microbiol Lett. 1993;111(1):31-36.

[103] Smith JM, Davies JE, Holden DW. Construction and pathogenicity of Aspergillus fumigatus mutants that do not produce the ribotoxin restrictocin. Mol Microbiol. 1993;9(5):1071-1077.

[104] Brooks JE, Blumenthal RM, Gingeras TR. The isolation and characterization of the Escherichia coli DNA adenine methylase (dam) gene. Nucleic Acids Res. 1983;11(3):837-851.

[105] Kaper JB, Nataro JP, Mobley HL. Pathogenic Escherichia coli. Nat Rev Microbiol. 2004;2(2):123140 . 
[106] Low DA, Weyand NJ, Mahan MJ. Roles of DNA adenine methylation in regulating bacterial gene expression and virulence. Infect Immun. 2001; 69(12):7197-7204.

[107] Barras F, Marinus MG. The great GATC: DNA methylation in E coli. Trends Genet. 1989;5(5):139143.

[108] Prieto AI, Ramos-Morales F, Casadesus J. Bileinduced DNA damage in Salmonella enterica. Genetics. 2004;168(4):1787-1794.

[109] Pucciarelli MG, Prieto AI, Casadesús J, García-del Portillo F. Envelope instability in DNA adenine methylase mutants of Salmonella enterica. Microbiology. 2002;148(pt 4):1171-1182.

[110] Unger E, Betz S, Xu R, Cigan AM. Selection and orientation of adjacent genes influences DAMmediated male sterility in transformed maize. Transgenic Res. 2001;10(5):409-422.

[111] Barbeyron T, Kean K, Forterre P. DNA adenine methylation of GATC sequences appeared recently in the Escherichia coli lineage. J Bacteriol. 1984;160(2):586-590.

[112] Stamm LV, Greene SR, Barnes NY, Bergen HL, Hardham JM. Identification and characterization of a Treponema pallidum subsp. pallidum gene encoding a DNA adenine methyltransferase. FEMS Microbiol Lett. 1997;155(1):115-119.

[113] Schlagman SL, Miner Z, Feher Z, Hattman S. The DNA [adenine- $\mathrm{N}^{6}$ ]methyltransferase (Dam) of bacteriophage T4. Gene. 1988;73(2):517-530.

[114] Yang Z, Kovar J, Kim J, et al. Identification of common subpopulations of non-sorbitol-fermenting, beta-glucuronidase-negative Escherichia coli O157: $\mathrm{H} 7$ from bovine production environments and human clinical samples. Appl Environ Microbiol. 2004;70(11):6846-6854.

[115] Hattman S, Wilkinson J, Swinton D, Schlagman S, Macdonald PM, Mosig G. Common evolutionary origin of the phage T4 dam and host Escherichia coli dam DNA-adenine methyltransferase genes. $J$ Bacteriol. 1985;164(2):932-937.

[116] Allison GE, Angeles D, Tran-Dinh N, Verma NK. Complete genomic sequence of SfV, a serotypeconverting temperate bacteriophage of Shigella flexneri. J Bacteriol. 2002;184(7):1974-1987.

[117] Kapfhammer D, Blass J, Evers S, Reidl J. Vibrio cholerae phage K139: complete genome sequence and comparative genomics of related phages. J Bacteriol. 2002;184(23):6592-6601.

[118] Remedyne. Founders of Remedyne's D.A.M. Antimicrobial Technology Featured in American Society of Microbiology News. Santa Barbara, Calif: Remedyne; 2001. http://www.remedyne.com/releases/ relase7_10_01.html.

[119] Nowrouzian F, Hesselmar B, Saalman R, et al. Escherichia coli in infants' intestinal microflora: colonization rate, strain turnover, and virulence gene carriage. Pediatr Res. 2003;54(1):8-14.
[120] Klee HJ, Hayford MB, Kretzmer KA, Barry GF, Kishore GM. Control of ethylene synthesis by expression of a bacterial enzyme in transgenic tomato plants. Plant Cell. 1991;3(11):1187-1193.

[121] Nelson KE, Weinel C, Paulsen IT, et al. Complete genome sequence and comparative analysis of the metabolically versatile Pseudomonas putida KT2440. Environ Microbiol. 2002;4(12):799-808.

[122] Belimov AA, Safronova VI, Sergeyeva TA, et al. Characterization of plant growth promoting rhizobacteria isolated from polluted soils and containing 1-aminocyclopropane-1-carboxylate deaminase. Can J Microbiol. 2001;47(7):642-652.

[123] Jia YJ, Kakuta Y, Sugawara M, et al. Synthesis and degradation of 1-aminocyclopropane-1-carboxylic acid by Penicillium citrinum. Biosci Biotechnol Biochem. 1999;63(3):542-549.

[124] Ghosh S, Penterman JN, Little RD, Chavez R, Glick BR. Three newly isolated plant growthpromoting bacilli facilitate the seedling growth of canola, Brassica campestris. Plant Physiol Biochem. 2003;41:277-281.

[125] Ma W, Sebestianova SB, Sebestian J, Burd GI, Guinel FC, Glick BR. Prevalence of 1-aminocyclopropane-1-carboxylate deaminase in Rhizobium spp. Antonie Van Leeuwenhoek. 2003;83(3):285291.

[126] Hontzeas N, Zoidakis J, Glick BR, Abu-Omar MM. Expression and characterization of 1aminocyclopropane-1-carboxylate deaminase from the rhizobacterium Pseudomonas putida UW4: a key enzyme in bacterial plant growth promotion. Biochim Biophys Acta. 2004;1703(1):11-19.

[127] Wanga C, Ramettea A, Punjasamarnwong P, et al. Cosmopolitan distribution of phlD-containing dicotyledonous crop-associated biocontrol pseudomonads of worldwide origin. FEMS Microbiology Ecology. 2001;37(2):105-116.

[128] Good X, Kellogg JA, Wagoner W, Langhoff D, Matsumura W, Bestwick RK. Reduced ethylene synthesis by transgenic tomatoes expressing Sadenosylmethionine hydrolase. Plant Mol Biol. 1994;26(3):781-790.

[129] Hughes JA, Brown LR, Ferro AJ. Nucleotide sequence and analysis of the coliphage T3 S-adenosylmethionine hydrolase gene and its surrounding ribonuclease III processing sites. Nucleic Acids Res. 1987;15(2):717-729.

[130] Macintyre G, Atwood CV, Cupples CG. Lowering S-adenosylmethionine levels in Escherichia coli modulates C-to-T transition mutations. J Bacteriol. 2001;183(3):921-927.

[131] Posnick LM, Samson LD. Influence of Sadenosylmethionine pool size on spontaneous mutation, dam methylation, and cell growth of Escherichia coli. J Bacteriol. 1999;181(21):6756-6762.

[132] Val DL, Cronan JE Jr. In vivo evidence that S-adenosylmethionine and fatty acid synthesis 
intermediates are the substrates for the LuxI family of autoinducer synthases. J Bacteriol. 1998;180(10): 2644-2651.

[133] Pajunen MI, Kiljunen SJ, Soderholm ME, Skurnik M. Complete genomic sequence of the lytic bacteriophage $\phi \mathrm{YeO} 3-12$ of Yersinia enterocolitica serotype O:3. J Bacteriol. 2001;183(6):1928-1937.

[134] Kiljunen S, Vilen H, Pajunen M, Savilahti H, Skurnik M. Nonessential genes of phage $\phi \mathrm{YeO} 3-$ 12 include genes involved in adaptation to growth on Yersinia enterocolitica serotype O:3. J Bacteriol. 2005;187(4):1405-1414.

[135] Pajunen MI, Elizondo MR, Skurnik M, Kieleczawa J, Molineux IJ. Complete nucleotide sequence and likely recombinatorial origin of bacteriophage T3. J Mol Biol. 2002;319(5):1115-1132.

[136] Wilson KJ, Hughes SG, Jefferson RA. The Escherichia coli gus operon: induction and expression of the gus operon in E coli and the occurrence and use of GUS in other bacteria. In: Gallagher SR, ed. GUS Protocols: Using the GUS Gene as a Reporter of Gene Expression. San Diego, Calif: Academic Press; 1992:7-22.

[137] Martin T, Wöhner R-V, Hummel S, Willmitzer L, Frommer WB. The GUS reporter system as a tool to study plant gene expression. In: Gallagher SR, ed. GUS Protocols: Using the GUS Gene as a Reporter of Gene Expression. San Diego, Calif:Academic Press; 1992:23-43.

[138] Witcher DR, Hood EE, Peterson D, et al. Commercial production of $\beta$-glucuronidase (GUS): a model system for the production of proteins in plants. $\mathrm{Mol}$ Breed. 1998;4:301-312.

[139] Frampton EW, Restaino L. Methods for Escherichia coli identification in food, water and clinical samples based on beta-glucuronidase detection. J Appl Bacteriol. 1993;74(3):223-233.

[140] Ram JL, Ritchie RP, Fang J, Gonzales FS, Selegean JP. Sequence-based source tracking of Escherichia coli based on genetic diversity of $\beta$-glucuronidase. $J$ Environ Qual. 2004;33(3):1024-1032.

[141] Wenzl P, Wong L, Kwang-won K, Jefferson RA. A functional screen identifies lateral transfer of $\beta$ glucuronidase (gus) from bacteria to fungi. $\mathrm{Mol}$ Biol Evol. 2005;22(2):308-316.

[142] Feng P, Lum R, Chang GW. Identification of uidA gene sequences in $\beta$-D-glucuronidase-negative Escherichia coli. Appl Environ Microbiol. 1991;57(1): 320-323.

[143] Feng P, Lampel KA. Genetic analysis of uidA expression in enterohaemorrhagic Escherichia coli serotype O157:H7. Microbiology. 1994;140(pt 8):2101-2107.

[144] Monday SR, Whittam TS, Feng PC. Genetic and evolutionary analysis of mutations in the gusA gene that cause the absence of beta-glucuronidase activity in Escherichia coli O157:H7. J Infect Dis. 2001;184(7):918-921.
[145] Dontorou A, Papadopoulou C, Filioussis G, et al. Isolation of a rare Escherichia coli O157:H7 strain from farm animals in Greece. Comp Immunol Microbiol Infect Dis. 2004;27(3):201-207.

[146] Stewart L, Oesterle AL, Erdan I, Griffiss JM, Way LW. Pathogenesis of pigment gallstones in Western societies: the central role of bacteria. J Gastrointest Surg. 2002;6(6):891-904.

[147] Kemp JD, Sutton DW, Hack E. Purification and characterization of the crown gall specific enzyme nopaline synthase. Biochemistry. 1979;18(17):3755-3760.

[148] Zhu J, Oger PM, Schrammeijer B, Hooykaas PJ, Farrand SK, Winans SC. The bases of crown gall tumorigenesis. J Bacteriol. 2000;182(14):3885-3895.

[149] CFIA. Determination of the Safety of the Crop Development Centre's "CDC Triffid," a Flax (Linum usitatissimum L.) Variety Tolerant to Soil Residues of Triasulfuron and Metsulfuronmethyl. Nepean: Plant Biosafety Office, Plant Products Directorate, Canadian Food Inspection Agency: 1996. Decision Document 98-24 http://www.inspection.gc.ca/english/plaveg/bio/ dd/dd9824e.shtml.

[150] Monneuse MO, Rouzé P. Sequence comparisons between Agrobacterium tumefaciens T-DNAencoded octopine and nopaline dehydrogenases and other nucleotide-requiring enzymes: structural and evolutionary implications. $\mathrm{J} \mathrm{Mol} \mathrm{Evol.}$ 1987;25:46-57.

[151] Dairi T, Asano Y. Cloning, nucleotide sequencing, and expression of an opine dehydrogenase gene from Arthrobacter sp. strain 1C. Appl Environ Microbiol. 1995;61(8):3169-3171.

[152] Kimura T, Nakano T, Yamaguchi T, et al. Complementary DNA cloning and molecular evolution of opine dehydrogenases in some marine invertebrates. Mar Biotechnol (NY). 2004;6(5):493-502.

[153] Nester E, Wood D, Piu L. Global analysis of Agrobacterium-plant interactions. In: Tsuyumu S, Leach JE, Shiraishi T, Wolpert T, eds. Genomic and Genetic Analysis of Plant Parasitism and Defense, Proceedings of the 9th Japan US Science Seminar on Plant Pathogens, Shizuoka, Japan, November, 2003. Saint Paul, Minn:American Phytopathological Society; 2005:1-10.

[154] Teyssier-Cuvelle S, Mougel C, Nesme X. Direct conjugal transfers of Ti plasmid to soil microflora. $\mathrm{Mol}$ Ecol. 1999;8(8):1273-1284.

[155] Otten L, De Ruffray P. Agrobacterium vitis nopaline Ti plasmid pTiAB4: relationship to other $\mathrm{Ti}$ plasmids and T-DNA structure. Mol Gen Genet. 1994;245(4):493-505.

[156] Beegle CC, Yamamoto T. History of Bacillus thuringiensis Berliner research and development. Can Entomol. 1992;124:587-616.

[157] IPCS. Bacillus thuringiensis. Environmental Health Criteria 217. Geneva, Switzerland:International 
Program on Chemical Safety, World Health Organization, 1999.

[158] Crickmore N, Zeigler DR, Schnepf E, et al. Bacillus thuringiensis Toxin Nomenclature. Falmer, Brighton:University of Sussex; 2005. http://www. biols.susx.ac.uk/home/Neil_Crickmore/.

[159] Geiser M, Schweitzer S, Grimm C. The hypervariable region in the genes coding for entomopathogenic crystal proteins of Bacillus thuringiensis: nucleotide sequence of the kurhd1 gene of subsp kurstaki HD1. Gene. 1986;48(1):109-118.

[160] Adang MJ, Staver MJ, Rocheleau TA, Leighton J, Barker RF, Thompson DV. Characterized fulllength and truncated plasmid clones of the crystal protein of Bacillus thuringiensis subsp kurstaki HD-73 and their toxicity to Manduca sexta. Gene. 1985;36(3):289-300.

[161] Chambers JA, Jelen A, Gilbert MP, Jany CS, Johnson TB, Gawron-Burke C. Isolation and characterization of a novel insecticidal crystal protein gene from Bacillus thuringiensis subsp aizawai. J Bacteriol. 1991;173(13):3966-3976.

[162] Donovan WP, Dankocsik CC, Gilbert MP, GawronBurke MC, Groat RG, Carlton BC. Amino acid sequence and entomocidal activity of the P2 crystal protein. An insect toxin from Bacillus thuringiensis var kurstaki. [Erratum in J Biol Chem. 1989;264(8):4740]. J Biol Chem. 1988;263(1):5617.

[163] Dankocsik C, Donovan WP, Jany CS. Activation of a cryptic crystal protein gene of Bacillus thuringiensis subspecies kurstaki by gene fusion and determination of the crystal protein insecticidal specificity. Mol Microbiol. 1990;4(12):20872094.

[164] McPherson S, Perlak F, Fuchs R, Marrone P, Lavrik P, Fischhoff D. Characterization of the coleopteranspecific protein gene of Bacillus thuringiensis var tenebrionis. Biotechnology. 1988;6:61-66.

[165] Donovan WP, Rupar MJ, Slaney AC, Malvar T, Gawron-Burke MC, Johnson TB. Characterization of two genes encoding Bacillus thuringiensis insecticidal crystal proteins toxic to Coleoptera species. Appl Environ Microbiol. 1992;58(12):3921-3927.

[166] Moellenbeck DJ, Peters ML, Bing JW, et al. Insecticidal proteins from Bacillus thuringiensis protect corn from corn rootworms. Nat Biotechnol. 2001;19(7):668-672.

[167] Damgaard PH, Larsen HD, Hansen BM, Bresciani J, Jorgensen K. Enterotoxin-producing strains of Bacillus thuringiensis isolated from food. Lett Appl Microbiol. 1996;23(3):146-150.

[168] Ichimatsu T, Mizuki E, Nishimura K, et al. Occurrence of Bacillus thuringiensis in fresh waters of Japan. Curr Microbiol. 2000;40(4):217-220.

[169] Kaelin P, Gadani F. Occurrence of Bacillus thuringiensis on cured tobacco leaves. Curr Microbiol. 2000;40(3):205-209.
[170] Maeda M, Mizuki E, Nakamura Y, Hatano T, Ohba M. Recovery of Bacillus thuringiensis from marine sediments of Japan. Curr Microbiol. 2000; 40(6):418-422.

[171] Crickmore N, Zeigler DR, Feitelson J, et al. Revision of the nomenclature for the Bacillus thuringiensis pesticidal crystal proteins. Microbiol Mol Biol Rev. 1998;62(3):807-813.

[172] de Maagd RA, Bravo A, Crickmore N. How Bacillus thuringiensis has evolved specific toxins to colonize the insect world. Trends Genet. 2001;17(4):193199.

[173] Noteborn HPJM, Bienenmann-Ploum ME, van den Berg JHJ, et al. Safety assessment of the Bacillus thuringiensis insecticidal crystal protein CRYIA(b) expressed in transgenic tomatoes. In: Engel K-H, Takeoka GR, Teranishi R, eds. Genetically Modified Foods-Safety Aspects. vol. 605 of ACS Symposium Series. Washington DC: American Chemical Society; 1995:134-147.

[174] Betz FS, Hammond BG, Fuchs RL. Safety and advantages of Bacillus thuringiensis-protected plants to control insect pests. Regul Toxicol Pharmacol. 2000;32(2):156-173.

[175] Porcar M, Juarez-Perez V. PCR-based identification of Bacillus thuringiensis pesticidal crystal genes. FEMS Microbiol Rev. 2003;26(5):419-432.

[176] Wang J, Boets A, Van Rie J, Ren G. Characterization of cry1, cry2, and cry9 genes in Bacillus thuringiensis isolates from China. J Invertebr Pathol., 2003; 82(1):63-71.

[177] Chen FC, Tsai MC, Peng CH, Chak KF. Dissection of cry gene profiles of Bacillus thuringiensis isolates in Taiwan. Curr Microbiol. 2004;48(4):270-275.

[178] Uribe D, Martinez W, Ceron J. Distribution and diversity of cry genes in native strains of Bacillus thuringiensis obtained from different ecosystems from Colombia. J Invertebr Pathol. 2003;82(2):119127.

[179] Barloy F, Lecadet MM, Delecluse A. Distribution of clostridial cry-like genes among Bacillus thuringiensis and Clostridium strains. Curr Microbiol. 1998;36(4):232-237.

[180] Yokoyama T, Tanaka M, Hasegawa M. Novel cry gene from Paenibacillus lentimorbus strain Semadara inhibits ingestion and promotes insecticidal activity in Anomala cuprea larvae. J Invertebr Pathol. 2004;85(1):25-32.

[181] Zhang J, Hodgman TC, Krieger L, Schnetter W, Schairer HU. Cloning and analysis of the first cry gene from Bacillus popilliae. J Bacteriol. 1997;179(13):4336-4341.

[182] Baumann L, Broadwell AH, Baumann P. Sequence analysis of the mosquitocidal toxin genes encoding 51.4- and 41.9-kilodalton proteins from Bacillus sphaericus 2362 and 2297. J Bacteriol. 1988;170(5):2045-2050. 
[183] Ellis RT, Stockhoff BA, Stamp L, et al. Novel Bacillus thuringiensis binary insecticidal crystal proteins active on western corn rootworm, Diabrotica virgifera virgifera LeConte. Appl Environ Microbiol. 2002;68(3):1137-1145.

[184] Hernández CS, Andrew R, Bel Y, Ferré J. Isolation and toxicity of Bacillus thuringiensis from potato-growing areas in Bolivia. J Invertebr Pathol. 2005;88(1):8-16.

[185] Swiecicka I, Mahillon J. The clonal structure of Bacillus thuringiensis isolates from north-east Poland does not correlate with their cry gene diversity. Environ Microbiol. 2005;7(1):34-39.

[186] Vilas-Bôas GT, Lemos MVF. Diversity of cry genes and genetic characterization of Bacillus thuringiensis isolated from Brazil. Can J Microbiol. 2004;50(8):605-613.

[187] Carlson CR, Kolsto AB. A complete physical map of a Bacillus thuringiensis chromosome. J Bacteriol. 1993;175(4):1053-1060.

[188] Hu X, Hansen BM, Eilenberg J, et al. Conjugative transfer, stability and expression of a plasmid encoding a crylAc gene in Bacillus cereus group strains. FEMS Microbiol Lett. 2004;231(1):45-52.

[189] Vilas-Bôas GFLT, Vilas-Bôas LA, Lereclus D, Arantes OMN. Bacillus thuringiensis conjugation under environmental conditions. FEMS Microbiol Ecol. 1998;25:369-374.

[190] Schnepf E, Crickmore N, Van Rie J, et al. Bacillus thuringiensis and its pesticidal crystal proteins. $\mathrm{Mi}$ crobiol Mol Biol Rev. 1998;62(3):775-806.

[191] Helgason E, Økstad OA, Caugant DA, et al. Bacillus anthracis, Bacillus cereus, and Bacillus thuringiensis - one species on the basis of genetic evidence. Appl Environ Microbiol. 2000;66(6):26272630.

[192] Siegel JP. The mammalian safety of Bacillus thuringiensis-based insecticides. J Invertebr Pathol. 2001;77(1):13-21. 

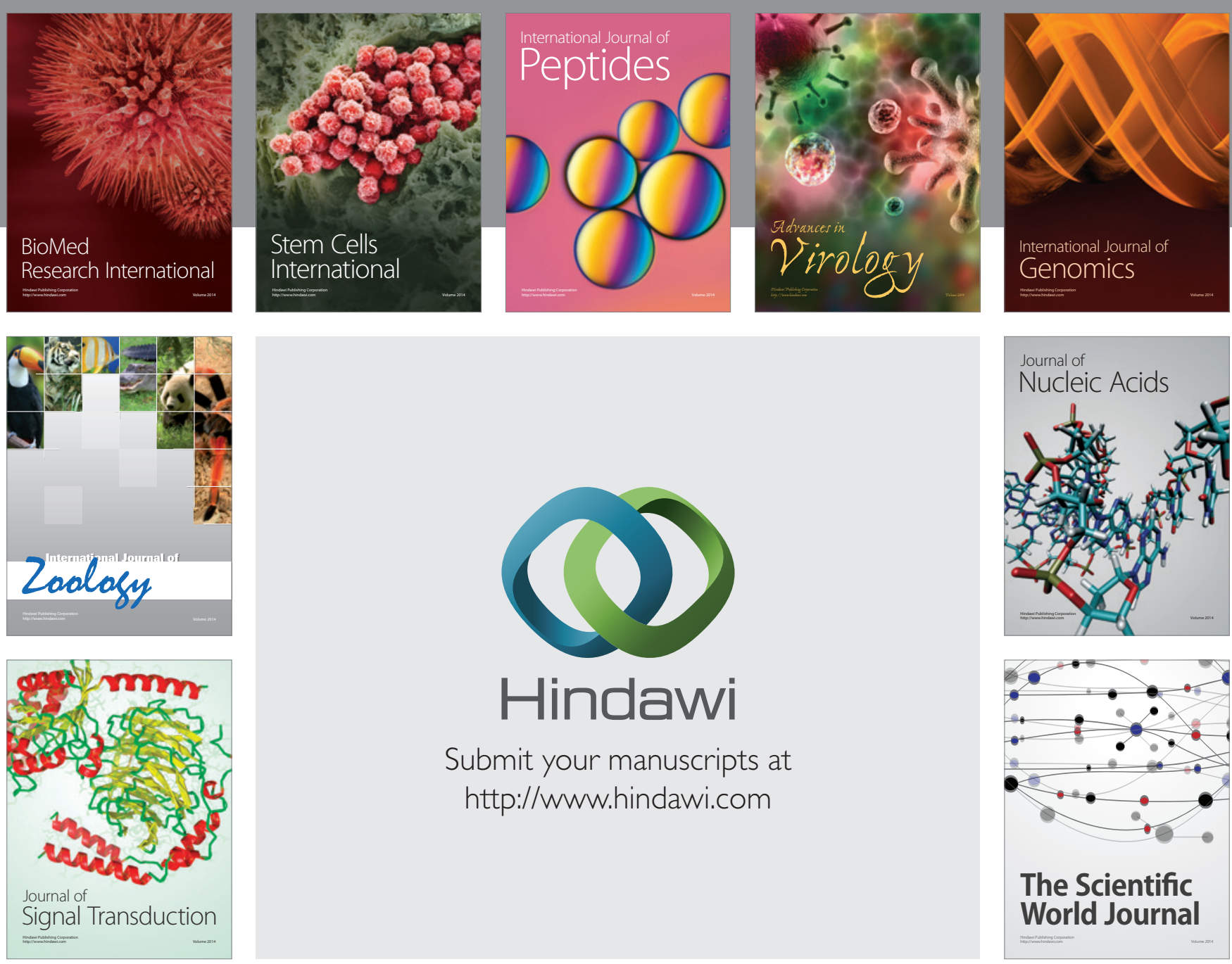

Submit your manuscripts at

http://www.hindawi.com
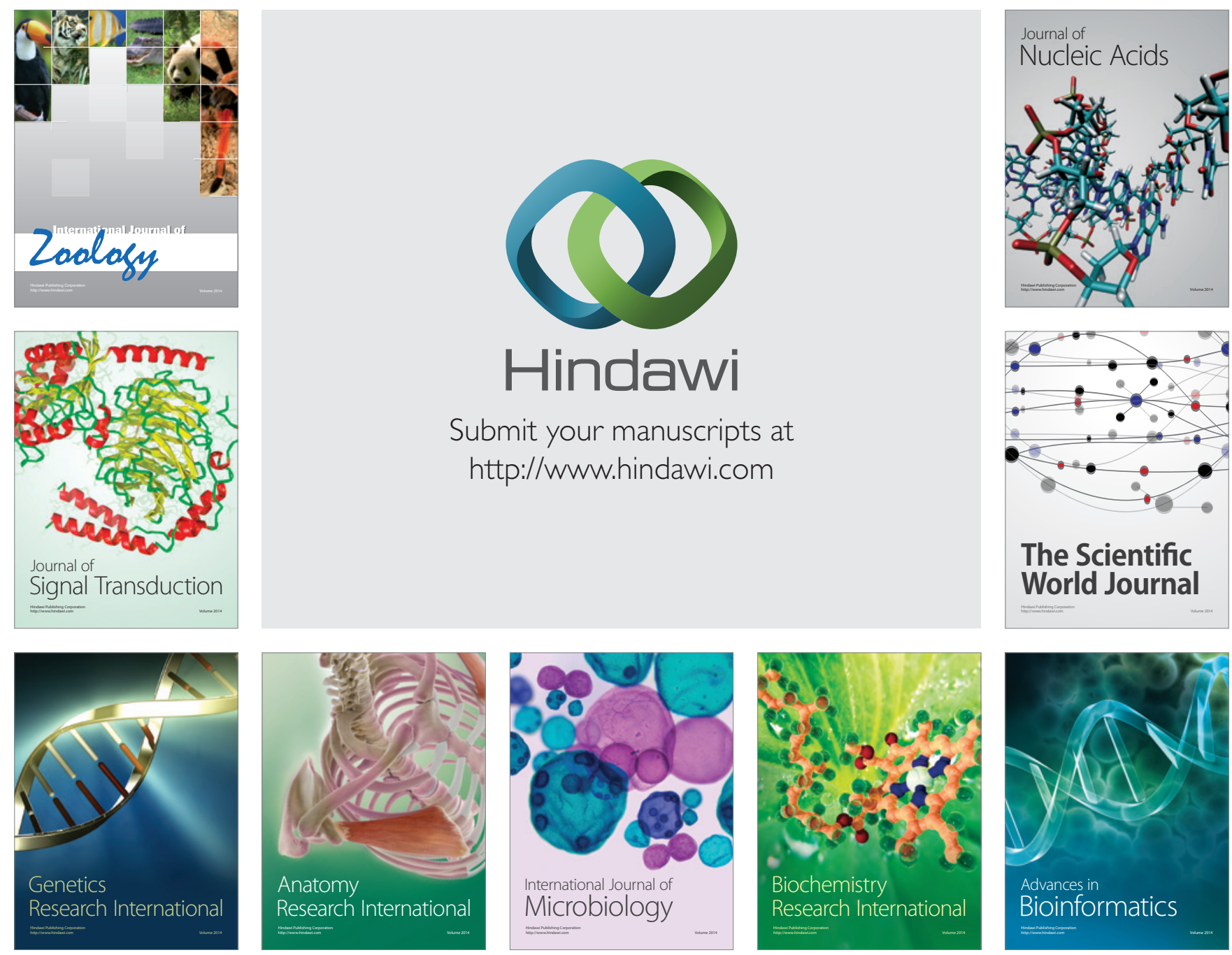

The Scientific World Journal
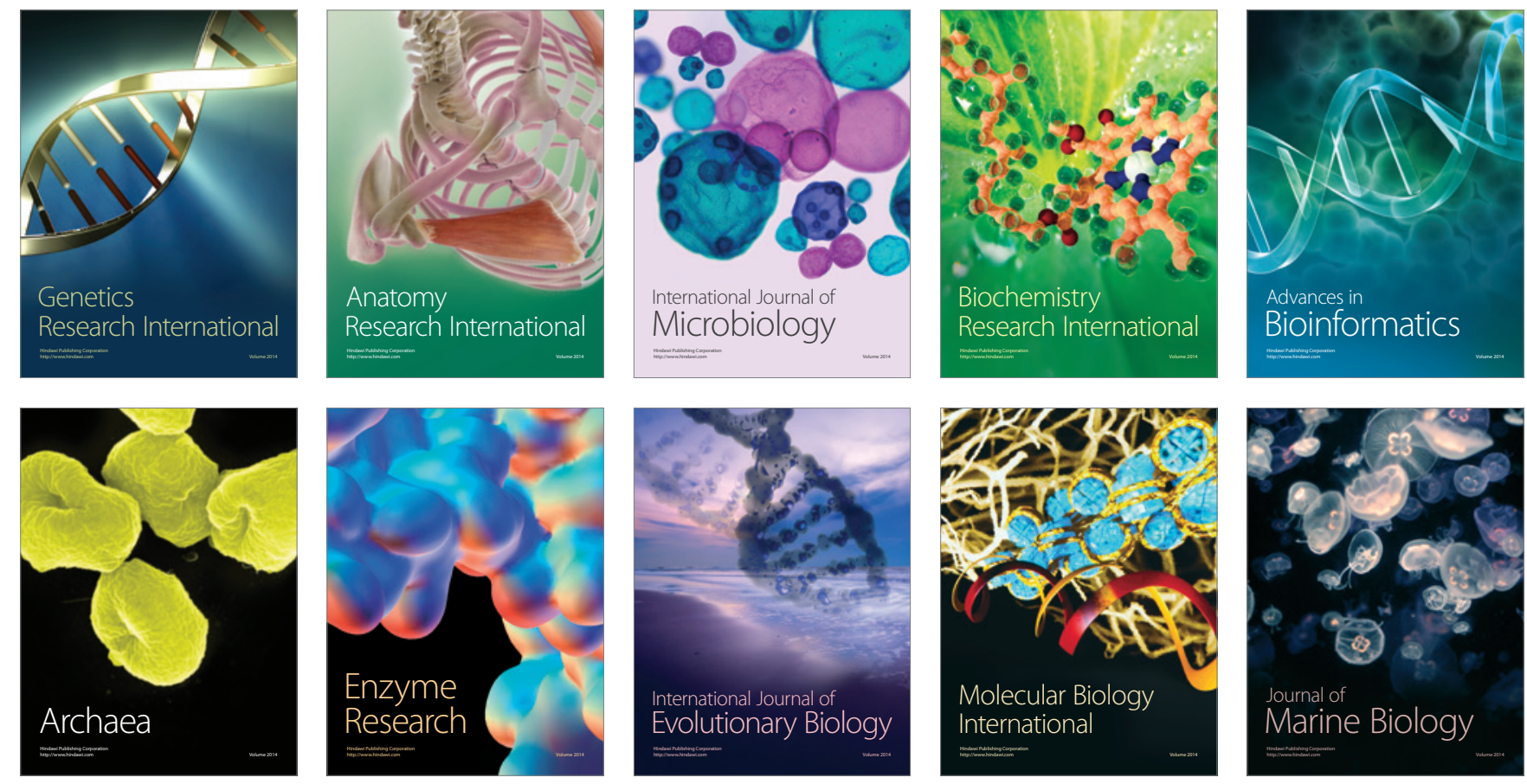